\title{
Microclimatic edge-to-interior gradients of European deciduous forests
}

\section{Camille Meeussen $^{\mathrm{a}, *}$, Sanne Govaert ${ }^{\mathrm{a}}$, Thomas Vanneste ${ }^{\mathrm{a}}$, Kurt Bollmann ${ }^{\mathrm{b}}$, Jörg Brunet ${ }^{\mathrm{c}}$, Kim Calders ${ }^{\mathrm{d}}$, Sara A.O. Cousins ${ }^{\mathrm{e}, \mathrm{i}}$, Karen De Pauw ${ }^{\mathrm{a}}$, Martin Diekmann ${ }^{\mathrm{f}}$, Cristina Gasperini ${ }^{\mathrm{g}}{ }^{\text {, a }}$, Per-Ola Hedwall ${ }^{c}$, Kristoffer Hylander ${ }^{\text {h,i }}$, Giovanni Iacopetti ${ }^{g}$, Jonathan Lenoir ${ }^{j}$, Sigrid Lindmo $^{\mathrm{k}}$, Anna Orczewska ${ }^{\mathrm{l}}$, Quentin Ponette ${ }^{\mathrm{m}}$, Jan Plue ${ }^{\mathrm{e}}$, Pieter Sanczuk ${ }^{\mathrm{a}}$, Federico Selvi $^{\mathrm{g}}$, Fabien Spicher ${ }^{\mathrm{j}}$, Hans Verbeeck ${ }^{\mathrm{d}}$, Florian Zellweger ${ }^{\mathrm{b}}$, Kris Verheyen ${ }^{\mathrm{a}}$, Pieter Vangansbeke ${ }^{\mathrm{a}}$, Pieter De Frenne ${ }^{\mathrm{a}}$}

${ }^{\text {a }}$ Forest \& Nature Lab, Department of Environment, Ghent University, 9090 Melle-Gontrode, Belgium

${ }^{\mathrm{b}}$ Swiss Federal Institute for Forest, Snow and Landscape Research WSL, 8903 Birmensdorf, Switzerland

c Southern Swedish Forest Research Centre, Swedish University of Agricultural Sciences, 23422 Lomma, Sweden

${ }^{\mathrm{d}}$ CAVElab - Computational and Applied Vegetation Ecology, Department of Environment, Ghent University, 9000 Ghent, Belgium

${ }^{\mathrm{e}}$ Landscape, Environment and Geomatics, Department of Physical Geography, Stockholm University, 10691 Stockholm, Sweden

${ }^{\mathrm{f}}$ Vegetation Ecology and Conservation Biology, Institute of Ecology, FB2, University of Bremen, 28359 Bremen, Germany

${ }^{\mathrm{g}}$ Department of Agriculture, Food, Environment and Forestry, University of Florence, 50144 Florence, Italy

${ }^{\mathrm{h}}$ Department of Ecology, Environment and Plant Sciences, Stockholm University, 10691 Stockholm, Sweden

${ }^{\mathrm{i}}$ Bolin Centre for Climate Research, Stockholm University, 10691 Stockholm, Sweden

${ }^{\mathrm{j}}$ UMR 7058 CNRS Ecologie et Dynamique des Systèmes Anthropisés (EDYSAN), Université de Picardie Jules Verne, 80000 Amiens, France

${ }^{\mathrm{k}}$ Department of Biology, Norwegian University of Science and Technology, 7491 Trondheim, Norway

${ }^{1}$ Institute of Biology, Biotechnology and Environmental Protection, Faculty of Natural Sciences, University of Silesia, 40-007 Katowice, Poland

${ }^{\mathrm{m}}$ Earth and Life Institute, Université catholique de Louvain, 1348 Louvain-la-Neuve, Belgium

\section{A R T I C L E I N F O}

\section{Keywords:}

Climate change

Edge influence

Forest structure

Fragmentation

Temperate forests

Temperature buffering

\begin{abstract}
A B S T R A C T
Global forest cover is heavily fragmented. Due to high edge-to-surface ratios in small forest patches, a large proportion of forests is affected by edge influences involving steep microclimatic gradients. Although forest edges are important ecotones and account for $20 \%$ of the global forested area, it remains unclear how biotic and abiotic drivers affect forest edge microclimates at the continental scale. Here we report soil and air temperatures measured in 225 deciduous forest plots across Europe for two years. Forest stands were situated along a latitudinal gradient and subject to a varying vegetation structure as quantified by terrestrial laser scanning. In summer, the average offset of air and soil temperatures in forest edges compared to temperatures outside the forest amounted to $-2.8{ }^{\circ} \mathrm{C}$ and $-2.3{ }^{\circ} \mathrm{C}$, respectively. Edge-to-interior summer temperature gradients were affected by the macroclimate and edge structure. From the edge onwards, larger offsets were observed in dense forest edges and in warmer, southern regions. In open forests and northern Europe, altered microclimatic conditions extended deeper into the forest and gradients were steeper. Canopy closure and plant area index were important drivers of summer offsets in edges, whereas in winter also the forest-floor biomass played a key role. Using high-resolution maps, we estimated that approximately $10 \%$ of the European broadleaved forests would be affected by altered temperature regimes. Gradual transition zones between forest and adjacent lands are valuable habitat types for edge species. However, if cool and moist forest interiors are desired, then (i) dense and complex forest edges, (ii) an undisturbed forested buffer zone of at least $12.5 \mathrm{~m}$ deep and (iii) trees with a high shade casting ability could all contribute to an increased offset. These findings provide important guidelines to mitigate edge influences, to protect typical forest microclimates and to adapt forest management to climate change.
\end{abstract}

\footnotetext{
* Corresponding author.

E-mail address: Camille.meeussen@ugent.be (C. Meeussen).
} 


\section{Introduction}

Global temperatures have increased by approximately $1{ }^{\circ} \mathrm{C}$ in the past century and are expected to rise further (IPCC, 2018). However, at local scales such as in forest stands, worldwide warming trends might be less pronounced and climate-change impacts on forest organisms living in the understory partly dampened (Bertrand et al., 2011; De Frenne et al., 2019; Zellweger et al., 2020). Indeed, the forest microclimate, the local climatic conditions below tree canopies, can differ considerably from the regional climate due to terrain features or vegetation structure and composition (Chen et al., 1999; Geiger et al., 2009), and therefore do not necessarily follow the same trends as regional temperature increases. Due to the shading and evaporation of the vegetation canopy, forest-floor organisms receive less light, less extreme temperatures and thereby lower temperature variability throughout the day and year in comparison to open areas (Chen et al., 1995; De Frenne et al., 2019; Zellweger et al., 2019). Understorey organisms can even experience an offset which is greater than the warming rates of air temperatures in the past decades (Frey et al., 2016; De Frenne et al., 2019). Considering forest microclimates are therefore important because they ultimately regulate the survival, growth and dispersal of forest-dwelling organisms and affect important forest ecosystem processes such as tree regeneration, and carbon and nutrient cycling (Aussenac, 2000; Riutta et al., 2012; Chen et al., 2018; De Frenne et al., 2021). Moreover, microclimatic conditions determine the community composition and might explain why certain communities lag behind macroclimate and not microclimate warming (De Frenne et al., 2013, 2015; Stevens et al., 2015; Zellweger et al., 2020).

Even within forests, large differences in incoming radiation, wind speed and direction, temperature and humidity occur at short spatial scales. Such local gradients in microclimatic conditions are especially pronounced near forest edges. These transition zones between forests and adjacent open land are characterised by strong inflow of warm or cool air, depending on the season and time of the day (Harper et al., 2005; Schmidt et al., 2017). Especially due to steep changes in vegetation structure and composition (Harper et al., 2005; Meeussen et al., 2020), forest edge zones are characterized by environmental gradients that can extend up to $100 \mathrm{~m}$ into the forest interior (Harper et al., 2005; Schmidt et al., 2017). For instance, during the summer, temperature and light levels decrease whereas the relative air humidity increases from the edge towards the forest interior (Matlack, 1993; Davies-Colley et al., 2000; Schmidt et al., 2017). This makes transition zones more susceptible to temperature extremes and drought stress in comparison to forest interiors. Altered microclimatic conditions in forest edges, from warm and dry at the edge to cool and moist in the interior, consequently create gradients in understorey biodiversity and induce the establishment of typical habitats for edge-loving vegetation and organisms (Magura, 2002; Ries et al., 2004; De Smedt et al., 2019; Govaert et al., 2020; De Pauw et al., 2021). Furthermore, they change ecosystem functioning and the provisioning of services such as carbon stocks and cycling (Remy et al., 2016; Meeussen et al., 2021). Forest microclimates have long been studied (Geiger et al., 2009; Schmidt et al., 2019), however, we still lack an assessment of the relative importance of local and regional drivers on the spatiotemporal variation of forest edge microclimates at the continental scale.

As a result of large-scale fragmentation, more than $20 \%$ of the global forest surface is situated within $100 \mathrm{~m}$ of a non-forested matrix (Haddad et al., 2015). In Europe alone, the cumulative edge length of broadleaved forests amounts to 9.4 billion metres (Meeussen et al., 2021). A substantial extent of the forested area in Europe is thus subject to strong edge influences and consequently to environmental and ecological gradients penetrating deep into the interior of fragmented forest patches. Such edge influences, and their magnitude and depth of influence, are hitherto difficult to quantify as they can vary across the globe due to factors such as forest structure and composition (i.e. deeper edge influences in more open canopies) and macroclimate (i.e. stronger offsets in warmer climates) (Aussenac; 2000; De Frenne et al., 2019; Lembrechts and Lenoir, 2019). Therefore, it is important to gather information on how the drivers of edge-to-interior microclimatic gradients vary at a continental scale.

Here we assessed air and soil temperature offsets and integrated cumulative evaporation (as a proxy for relative air humidity) in 225 plots in 45 European deciduous forest edges for two years. The forests differed in vegetation structure and complexity, and were situated along a latitudinal gradient from the Mediterranean to central Norway, crossing eight different countries. This study design enabled us to quantify the effect of macroclimate and edge structure on the spatiotemporal variation in microclimatic temperature offsets and evaporation from the edge of the forest towards the interior. We hypothesized to find strong gradients in temperature and evaporation as one moves away from the edge. Moreover, we expected temperature offsets to be strongest in warm, southern European regions and in forests with a dense edge structure, and to find effects of management and macroclimate on the edge-to-interior gradients in temperature. Secondly, to gain a more complete understanding of these patterns, we quantified the influence of several regional (landscape and macroclimatic) characteristics and local site conditions (i.e. forest structure, soil texture and forest-floor litter and humus biomass). In particular, we expected that vegetation structure would play an important role on the forest microclimate, especially during the summer, enabling us to provide guidelines on how to protect forest interior microclimates.

\section{Material and method}

\subsection{Study design}

Data were collected in 45 ancient mesic deciduous forests, mainly dominated by oaks (Quercus robur, Q. petraea or Q. cerris), with Fagus sylvatica, Betula pubescens, Populus tremula, Ulmus glabra, Alnus incana and Carpinus betulus as other (sub)dominant tree species. The stands were situated along a $2300 \mathrm{~km}$ long south-north gradient across Europe. Along this latitudinal gradient, nine regions were selected from Central Italy up to Central Norway, covering a mean annual temperature difference of approximately $13{ }^{\circ} \mathrm{C}$ (Fig. 1). In three of the nine regions, Norway, Belgium and Italy, an additional elevational gradient with three levels (i.e. low, intermediate and high elevational sites) was established as well to capture climatic variation resulting from elevational differences (expected temperature difference $\approx 5.76{ }^{\circ} \mathrm{C}$; ICAO, 1993). In total, 15 sites (i.e. nine lowland, three intermediate and three high-elevational sites) were selected across Europe.

In all sites $(n=15)$, three forest stands were selected with a different structure and management type (Fig. 1). The first type, referred to as 'dense forests', were always the most structurally complex stands. They had not been thinned for at least three decades or managed in the past ten years, and therefore comprised of a dense canopy (canopy openness $<10 \%$ ), high basal area ( $>20 \mathrm{~m}^{2}$ per ha) and a well-developed shrub layer. Intermediate forests, the second management type, were stands with a lower basal area (10-25 $\mathrm{m}^{2}$ per ha) and higher openness (5-30\%), resulting from regular but not too recent (at least five to ten years before sampling) thinning events. The third and final management type represented 'open forests'. These stands were even-aged with a simple structure without shrubs and a subdominant tree layer as they were intensively thinned one up to four years before sampling. Where possible, they were selected based on a low canopy openness (30-50\%) and low basal area $\left(<10-15 \mathrm{~m}^{2}\right.$ per ha). Further details on the study design, forest structure and site selection can be found in Govaert et al. (2020), Meeussen et al. (2020, 2021), De Pauw et al. (2021) and Sanczuk et al. (2021) as this paper is part of larger research project with a common same study design.

In each of the 45 forest stands, we studied a 100 m-long gradient perpendicular to the forest edge (Fig. 1). The edges all bordered a matrix of agricultural land and were approximately south-orientated. Edge 
Latitudinal and elevational gradient

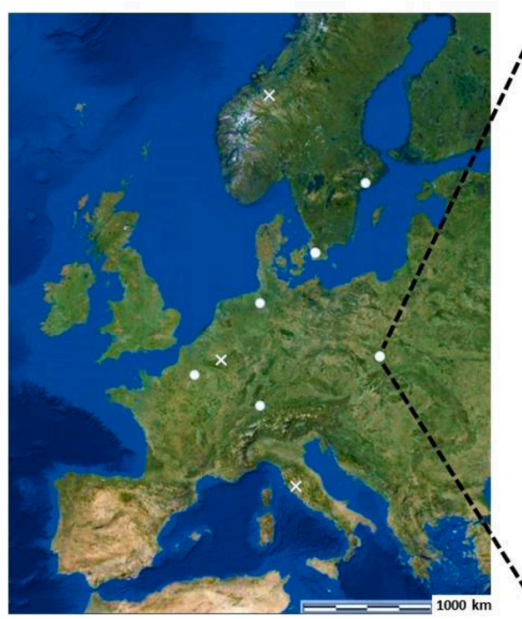

Management gradient

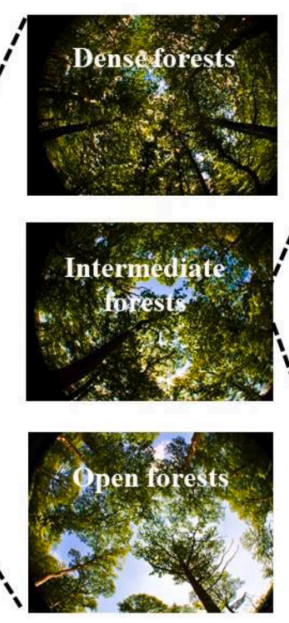

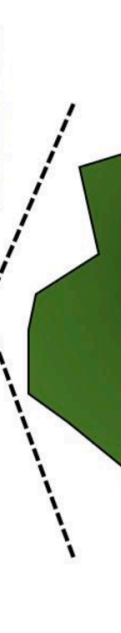

Edge-to-interiorgradient

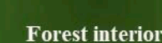

Forest interior

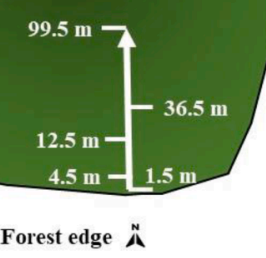

Fig. 1. Overview of the study design with the macroclimatic gradients (latitude and elevation) and forest structural gradients (management and distance to the edge). Left: The nine regions (Central Italy, Northern Switzerland, Northern France, Belgium, Southern Poland, Northern Germany, Southern Sweden, Central Sweden and Central Norway) along the latitudinal gradient, including three additional elevational gradients (shown as white crosses on the map). Background map from: http://da tabasin.org. Middle: The three forest management types. Right: An example of a 100 m-long edge-to-interior gradient, whereby the forest edge is defined as the outermost line of tree trunks bordering the non-forested matrix. The forest interior is the forest area not characterized by edge influences, where abiotic and biotic conditions thus stay relatively homogenous. Figure after Meeussen et al. (2021), reproduced with permission. orientation was kept constant, because of its known impact on microclimate and depth of edge influence through exposure to direct radiation (Matlack, 1993; Chen et al., 1995; Murcia, 1995). Along each edge-to-interior gradient, five $3 \mathrm{~m}$ by $3 \mathrm{~m}$ plots were established at predefined distances from the forest edge towards the core following an exponential curve $(n=225)$, as the strongest changes in microclimatic conditions were expected to occur near the forest edge. The centre of the first plot was situated at a distance of $1.5 \mathrm{~m}$ from the edge, a second plot was located at $4.5 \mathrm{~m}$ from the edge and three more plots were centred at $12.5 \mathrm{~m}, 36.5 \mathrm{~m}$ and $99.5 \mathrm{~m}$ from the edge (Fig. 1). The fifth plot, situated at approximately $100 \mathrm{~m}$ from the forest edge, was considered representative of the forest's interior, a presumption in line with other studies finding the macroclimatic edge influences to dissipate within such a distance (Matlack, 1993; Young and Mitchell, 1994; Davies-Colley et al., 2000; Schmidt et al., 2017).

\subsection{Data collection}

\subsubsection{Microclimatic data}

We measured air and soil temperatures during two full years, from 1 June 2018 to 31 May 2020. Both air and soil temperatures were recorded at hourly intervals in each plot, using lascar temperature loggers (EasyLog EL-USB-1, accuracy at -35 to $+80{ }^{\circ} \mathrm{C}: \pm 0.5^{\circ} \mathrm{C}$ ). Air temperatures were measured at a height of $1 \mathrm{~m}$ above the forest floor. The sensors were attached to the north side of a wooden pole, which was placed in the centre of each plot, and were protected by plastic white radiation shields to avoid direct solar radiation on the sensors (Supplementary fig. A1). For the soil temperature, we buried the loggers horizontally in the ground in a protective plastic tube at a depth of $5 \mathrm{~cm}$ and $5 \mathrm{~cm}$ next to the wooden poles (Supplementary fig. A1). This set-up, the combination of the pole with air and soil data logger, was installed in each plot ( $n=450$ sensors) and repeated outside the forest for each of the fifteen sites ( $n=30$ reference sensors). The latter to quantify fully open conditions outside the forest to obtain reference macroclimate conditions not influenced by the forest canopy. All these 30 reference sensors (i.e. one soil and one air data logger per site) were installed in open grasslands in the vicinity (generally within a radius of $5 \mathrm{~km}$ ) of the respective forest edges.

After data collection, time series were visually checked for outliers (e.g. due to uprooting of the soil loggers by wild boar, broken radiation shields and poles) by plotting and comparing them with the other time series of sensors within the same site or the reference sensors. Biased temperature measurements, showing deviating trends or clear outliers, were removed from the dataset and subsequently daily minima, maxima and mean temperatures were determined for each sensor. Next, we calculated the daily mean (Tmean), minimum (Tmin) and maximum (Tmax) temperature offset, which corresponds to the temperature difference between each of the temperature loggers located along the edgeto-interior gradient and the reference temperature logger located in open conditions (offset $=$ edge-to-interior gradient location minus open reference location). Negative offsets thus depict cooler conditions inside the edge-to-interior gradient than in the open reference location, and vice versa. Finally, our daily temperature offset values were aggregated into monthly averages, and afterwards seasonal offsets (spring: March, April and May; summer: June, July and August; autumn: September, October and November; winter: December, January and February), if at least $50 \%$ of the data were available for that month/season. In the best case, we obtained 225 offset values (one per plot) for Tmean, Tmin and Tmax for both soil and air and during each season. To proceed, we mainly focused on the offset during winter and summer, as these seasons show the most contrasting patterns (Fig. 2 and Supplementary figure B1). Due to missing data, we were unable to calculate the summer air offsets in 2 plots, and the summer and winter soil offsets in 22 and 7 out of the 225 plots, respectively, due to for instance logger malfunctioning or the uprooting of soil sensors.

To quantify air humidity integrated over a longer time period, custom-built evaporometers were installed in May-June 2018. These evaporometers were narrow $50 \mathrm{~cm}$ long plastic tubes (diameter $14 \mathrm{~mm}$ ), cautiously sealed at the top with a plastic plug and at the bottom with an open cap covered by filter paper (Rotilabo ${ }^{\circledR}$-Blotting papers, thick. 1.0 $\mathrm{mm}$ ), functioning as Piche evaporometers (Papaioannou et al., 1996). The tubes were filled with c. $75 \mathrm{~mL}$ distilled water, weighted and carefully attached to the wooden pole with tape, at the north side and in such a manner that the tube hung vertically with its lower end $10 \mathrm{~cm}$ above the ground. After one month, the tubes were collected and again weighed to determine the water loss. The weight loss was finally converted to water evaporation in mm per week and served as a metric for the integrated, cumulative air humidity inside the forest over this period. Due to damaged filter paper in 24 tubes, 201 of the 225 measurement points were available for further analyses.

\subsubsection{Explanatory variables}

\subsubsection{Local site characteristics}

2.2.2.1.1. Forest structure and composition. The forest structure was quantified between May and July 2018. Primarily, we visually estimated the vertical species-specific cover of all shrub (1-7 m) and tree species $(>7 \mathrm{~m})$ in the 3 by $3 \mathrm{~m}$ plots. The average shade casting ability (SCA) was determined per plot, based on the SCA-score of individual trees and shrubs weighted by their respective cover. The SCA is an expert-based 


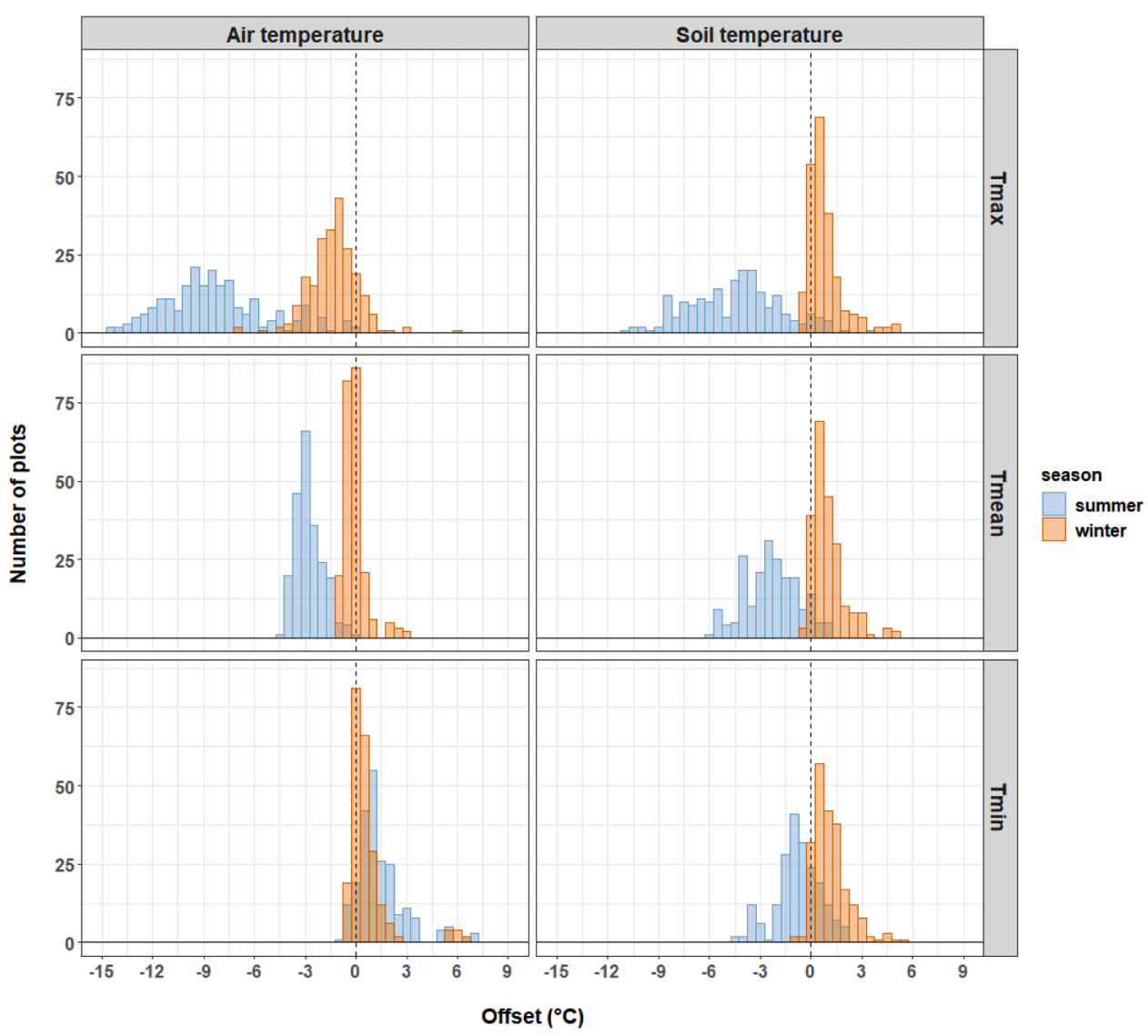

Fig. 2. Summary of the seasonal variation in air and soil temperature offsets $\left({ }^{\circ} \mathrm{C}\right)$ for maximum (Tmax), mean (Tmean) and minimum (Tmin) temperatures for all 225 study plots. Negative offsets indicate cooler temperatures inside forest edge zones.

and species-specific index, ranging between 1 and 5, describing the ability of trees and shrubs to cast low levels of shade (SCA close to one e. g. Betula pendula) or high levels of shade (SCA close to five e.g. Fagus sylvatica) (Verheyen et al., 2012). Species-specific SCA-scores were obtained from the literature (i.e. Verheyen et al., 2012 and Govaert et al., 2020) and are listed in the appendix (Table A1). Subsequently, in every plot, a larger circular plot with a $9 \mathrm{~m}$ radius was established. In these plots, the average diameter of all trees with a diameter at breast height (DBH, $1.3 \mathrm{~m}$ ) larger than $7.5 \mathrm{~cm}$ were determined via two DBH measurements per stem, perpendicular to each other, using a calliper. Subsequently, we calculated the total basal area per hectare at plot level. Next, we used terrestrial laser scanning (TLS) to further map the complex three-dimensional structure of the forest (Calders et al., 2020); all technical details considering this campaign are described in Meeussen et al. (2020). Single-scan position TLS was carried out in the centre of the plots using a RIEGL VZ400 (RIEGL Laser Measurement Systems $\mathrm{GmbH}$, Horn, Austria). Based on the scans, we derived four more forest structural metrics. Firstly, we determined the plant area index, a metric for plant material density or the total of the one-sided area of woody (e. g. branches) and non-woody biomass (i.e. leaves) per unit of surface area. More specifically, the plant area index was computed as the integral of the plant area per volume density (PAVD, $\mathrm{m}^{2} \mathrm{~m}^{-3}$ ) over the canopy top height. The plant area index of the shrub layer, as second metric, was determined as the total PAVD below a height of $7 \mathrm{~m}$. Thirdly, we determined the canopy top height, based on the $99 \%$ PAVD-percentile to remove atmospheric noise. Lastly, as a fourth TLS-derived metric, canopy closure was used. Canopy closure is the complement of canopy openness, which was calculated as the average percentage of gap fraction, the probability of a beam to miss all scattering elements in the forest (i.e. foliage or wood) and escape through the canopy, across the angle $5-70^{\circ}$.
2.2.2.1.2. Forest-floor biomass and soil texture. In addition, two more local site characteristics potentially affecting the forest microclimate were determined: the mass of the forest floor (i.e. litter and humus) and the soil texture (Paul et al., 2004; Fekete et al., 2016; Dutta et al., 2018). In each plot, one random sample of the forest floor, the organic material (i.e. O-horizon(s)) on top of the mineral topsoil, was taken in a $20 \mathrm{~cm}$ by $20 \mathrm{~cm}$ square frame after removal of live understorey vegetation. The litter and humus layers were sampled and weighed after drying to constant weight for $48 \mathrm{~h}$ at $65{ }^{\circ} \mathrm{C}$ to determine the biomass of the forest floor $\left(\mathrm{kg} \mathrm{m}^{-2}\right)$. Five subsamples of the soil were taken $(10-20 \mathrm{~cm}$ depth) in each plot as well. The subsamples were pooled per layer and dried to constant weight at $40{ }^{\circ} \mathrm{C}$ for $48 \mathrm{~h}$. Texture analysis was performed by sieving and sedimentation with a Robinson-Köhn pipette according to ISO 11277 (2009). We selected the percentage sand (\%) as most important proxy for the soil texture's influence on microclimate.

\subsubsection{Regional characteristics}

2.2.2.2.1. Macroclimate temperature and precipitation. Macroclimatic data were obtained from our reference sensors. For every site, we calculated the mean annual temperature (MAT, ${ }^{\circ} \mathrm{C}$, over the period 1 June 2018 to 31 May 2020) based on the data of the reference air sensors placed in the neighbourhood of our transects. Moreover, to obtain a more exact characterisation of the macroclimate during summer and winter, we also computed the mean seasonal temperature (MST, ${ }^{\circ} \mathrm{C}$ ) during winter and summer for both soil and air reference sensors. For each plot, data on the mean total annual precipitation (MAP, mm year ${ }^{-1}$ ) were extracted from CHELSA (version 1.2, average climatic conditions over the period 1979-2013 at a spatial resolution of 30', Karger et al., 2017). We also performed a sensitivity analysis using gridded macroclimate data (ERA5-Land hourly data, Muñoz Sabater, 2019) as reference data instead of our own open-habitat reference sensors. These 
sensitivity analyses confirm the robustness of our main findings and are available in Appendix C.

2.2.2.2.2. Landscape structure. Four landscape characteristics were extracted using satellite-based global tree cover data (spatial resolution of $30 \mathrm{~m}$, Hansen et al., 2013), a pan-European digital elevation model (spatial resolution of $25 \mathrm{~m}$ ), Copernicus data and information from the European Union (EU-DEM, 2018). The percentage of forest cover (\%, forests defined as surface areas with a minimum tree cover of $20 \%$ ) surrounding each plot was calculated using a circular buffer area with a $500 \mathrm{~m}$ radius (Hansen et al., 2013). Topographic northness and slope $\left(^{\circ}\right.$ ) were derived from the digital elevation model. The topographic northness, derived as the cosine of topographic aspect, represents the topographic exposition and ranges from north facing $(+1)$ to completely south facing (-1). Finally, also distance to the nearest coast was considered as a predictor of the microclimatic offset, as an increased temperature range and reduced air-mixing farther from the coast might affect the offset.

\subsection{Data analysis}

Variation in microclimatic gradients in forest edge zones across Europe was analysed in $\mathrm{R}$ version 4.0.3 (R Core Team, 2020) making use of linear mixed-effect models (Zuur et al., 2009) and the 'Imer' function in the R-package 'Ime4' (Bates et al., 2015). In all models, region and transect nested within region were added as random effect terms (i.e. random intercepts) to account for the nested structure of our design; plots nested in transects, nested in regions. In a first set of models, we studied the impact of distance to the edge, management type and the macroclimate (MAT, as a continuous variable for region and elevation) (i.e. our fixed effects) on the forest edge microclimate $(n \sim 225$ for the (winter and summer) air and soil temperature offset, and $n=201$ for the evaporation during the summer). Two-way interactions between fixed effects were allowed. Non-significant (interaction) effects were removed from the model during model selection using the 'step' function of the R-package 'ImerTest' (Kuznetsova et al., 2017). After model selection, restricted maximum likelihood was employed to assess the model parameters. Distance to the edge was log-transformed prior to analyses since the distribution of our plots followed an exponential pattern and one of the response variables, evaporation, had a right-skewed distribution and was log-transformed as well. If distance to the edge was a significant driver of the microclimate, a post hoc (Tukey Multiple Comparisons) test was executed using the ' $g l h t$ ' function ('multcomp' R-package) to explore up to which edge distance (here as a factor, significance level $p<0.05$ ) the microclimate differed from the microclimate in the forest interior (i.e. at a distance of $99.5 \mathrm{~m}$ from each edge) (Hothorn et al., 2008). This way we determined the depth of edge influence, and subsequently calculated, as a basic and explorative analysis, the percentage of European deciduous forests affected by edge influences in Europe based on the cumulative length of deciduous forest edges across Europe (Meeussen et al., 2021).

To achieve a more mechanistic understanding of the microclimate patterns and their drivers, an additional set of models was constructed. Here, the fixed effects were our local site features (shade casting ability (SCA), basal area, plant area index, plant area index of the shrub layer, canopy height, canopy openness, forest-floor biomass and soil texture) and regional landscape and macroclimatic characteristics (seasonal temperature (MST) from the reference sensor, precipitation (MAP), slope, northness, forest cover, and distance to the coast), whereas the random effects stayed the same (transect nested within region). Regarding MST, we always selected the macroclimatic temperature of the same type (air/soil) and same season (winter/summer) as the respective offset metric. For evaporation, the summer macroclimatic air temperature of the reference sensor was used. All continuous predictor variables were standardized to allow for a better comparison of model coefficients. No interaction terms were tested in these models (to make the models not overly complex), and again backward model selection was executed on this second set of models. Also, multicollinearity was tested making use of the variance inflation factor. Multicollinearity amongst the predictor variables in all models was low (variance inflation factors lower than 3 ).

\section{Results}

The average air temperature offset in summer across all plots and transects amounted to $-2.8 \pm 0.8{ }^{\circ} \mathrm{C}$ whereas in winter the average offset fluctuated around zero $\left(-0.1 \pm 0.7^{\circ} \mathrm{C}\right)$. Maximum summer air temperatures were on average $8.3 \pm 3.1{ }^{\circ} \mathrm{C}$ cooler inside than outside forests, in contrast, minimum summer air temperatures were warmer $\left(1.5 \pm 1.5^{\circ} \mathrm{C}\right)$ in the forest. Forest soil offsets were on average $-2.3 \pm$ $1.6{ }^{\circ} \mathrm{C}$ during the summer months, with a more negative offset for maximum temperatures $\left(-4.5 \pm 2.7^{\circ} \mathrm{C}\right)$ and minimum temperature offsets close to zero $\left(-0.8 \pm 1.3^{\circ} \mathrm{C}\right)$. In winter, mean, minimum and maximum soil temperatures were warmer inside than outside forests (respectively $1.0 \pm 1.0{ }^{\circ} \mathrm{C}, 1.1 \pm 1.0{ }^{\circ} \mathrm{C}$ and $0.8 \pm 1.0{ }^{\circ} \mathrm{C}$ ) (Fig. 2). The average summer evaporation amounted to $20.06 \mathrm{~mm}$ per week (range: 2.4-112.75 mm per week, Supplementary Fig.B2).

Besides seasonal fluctuations, the offset also depended on the macroclimate, management and distance to the edge (log-transformed). For almost all offset metrics, except for the offset of the minimum winter temperature in the forest soil, we found a significant main impact of the distance to the edge (Table 1, and Supplementary Tables B1 and B2) or edge distance interactions with MAT or forest type. In general, these trends indicated an enhanced cooling of mean and maximum temperatures (i.e. more negative offset) from the forest edge towards the interior during the summer (Fig. 3A and B), but in winter, higher mean and maximum temperatures (i.e. more positive offsets) were detected near the edge in comparison to the interior (Fig. 4). Moreover, we found an indication of a decreased evaporation in the interior, shown by the significant negative impact of the distance to the edge on the evaporation (Fig. 3C).

Interestingly, edge-to-interior gradients for the mean summer air offset were impacted by both management as well as macroclimate (Table 1, Fig. 3A). In summer, the mean air offset in open forests was lower than in dense forests, but, as shown by the interaction between management type and distance, dense forest edge zones showed a strong temperature offset directly at the edge and a more gradual decrease in offset towards the interior (Table 1, Fig. 3A). In open forests, on the other hand, there was a steep decrease in offset between edge and interior. Edges in open forests were thus subject to a reduced offset capacity and a stronger edge impact (Fig. 3A: effect of management type $\times$ distance shown in the different subpanels). Secondly, as demonstrated by the significant interaction between the distance to the edge and MAT, the cooling of mean temperatures in forest edge zones was more intense in warmer, southern regions but edge-to-interior gradients in colder, northern regions were steeper and stabilized farther into the forest interior (Fig. 3A: effect of MAT $\times$ distance shown by the different colours). In sum, the strongest reduction of mean summer sub-canopy temperatures could be found in dense forests located in warm regions, whereas in open forests offsets were lower and the depth of edge influence was higher. We found that offsets up to 12.5-36.5 $\mathrm{m}$ from the edge were significantly different from the offset in the forest interior ( $99.5 \mathrm{~m}$ from the edge) for the minimum summer air temperature and the mean and maximum air temperature in winter (Table 2).

In a second set of models (Table 3 and Supplementary Table B3), we studied the impact of regional and local site features on the offset and evaporation. During the summer, forest structural metrics were the main drivers of the cooling of mean and maximum temperatures in forest edge zones. In general, under canopies with a high plant area index and dense canopy closure there was a stronger, more negative, offset of mean and maximum temperatures in both air and soil (Fig. $5 \mathrm{a}$ and c). Furthermore, the canopy species composition also controlled air temperature offsets, with an enhanced cooling (i.e. more negative offset) under trees with a 
Table 1

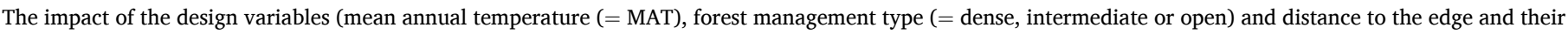

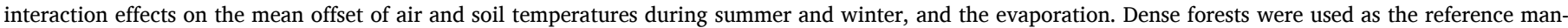

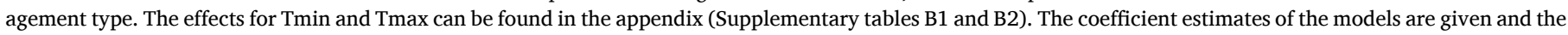
significance of the effect is indicated with asterisks $(*=p<0.05, * *=p<0.01, * * *=p<0.001)$.

\begin{tabular}{|c|c|c|c|c|c|}
\hline MEAN & $\begin{array}{l}\text { Summer air temperature } \\
\text { offset }\left({ }^{\circ} \mathrm{C}\right)\end{array}$ & $\begin{array}{l}\text { Summer soil temperature } \\
\text { offset }\left({ }^{\circ} \mathrm{C}\right)\end{array}$ & $\begin{array}{l}\text { Winter air temperature } \\
\text { offset }\left({ }^{\circ} \mathrm{C}\right)\end{array}$ & $\begin{array}{l}\text { Winter soil } \\
\text { temperature } \\
\text { offset }\left({ }^{\circ} \mathrm{C}\right)\end{array}$ & $\begin{array}{l}\text { Evaporation (log- } \\
\text { transformed, } \mathrm{mm} / \text { year) }\end{array}$ \\
\hline $\begin{array}{l}\text { Mean annual macroclimate } \\
\text { temperature (MAT) }\left({ }^{\circ} \mathrm{C}\right)\end{array}$ & -0.13 & $-1.57 * * *$ & $0.29 * *$ & $0.41 *$ & - \\
\hline Intermediate forests & 0.26 & - & - & - & - \\
\hline Open forests & $0.60 *$ & - & - & - & - \\
\hline $\begin{array}{l}\text { Distance to the edge (log- } \\
\text { transformed, } \mathrm{m})\end{array}$ & -0.08 * & $-0.22 * * *$ & $-0.09 * * *$ & $\begin{array}{l}-0.08 \\
* * *\end{array}$ & $-0.09 * *$ \\
\hline MAT $\times$ Distance & $0.07 * *$ & - & - & - & - \\
\hline MAT $\times$ Intermediate & - & - & - & - & - \\
\hline MAT $\times$ Open & - & - & - & - & - \\
\hline Intermediate $\times$ Distance & -0.04 & - & - & - & - \\
\hline Open $\times$ Distance & $-0.14 *$ & - & - & - & - \\
\hline
\end{tabular}
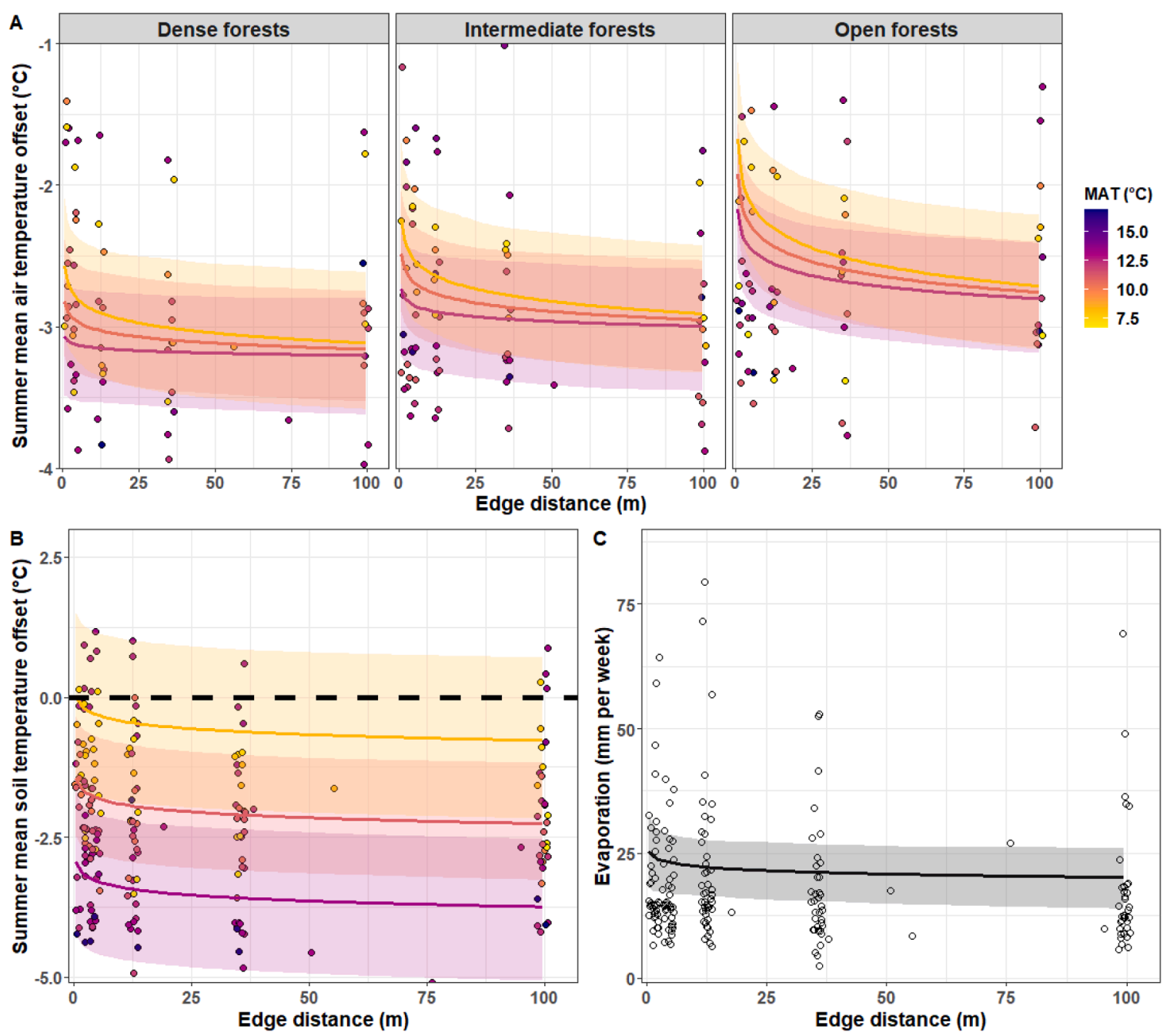

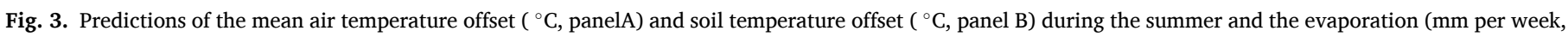

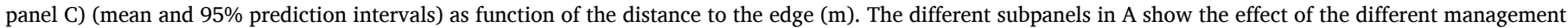

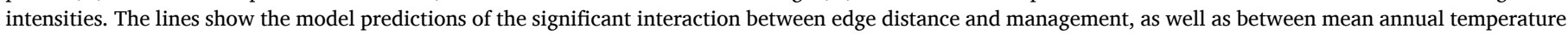

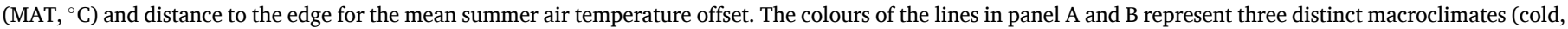

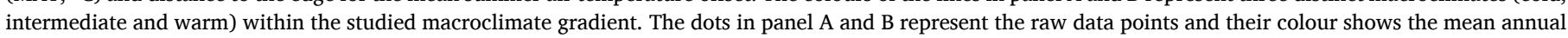
macroclimate temperature outside the forest (MAT, ${ }^{\circ} \mathrm{C}$ ); a small amount of jittering was added along the $\mathrm{x}$-axis to improve clarity. 

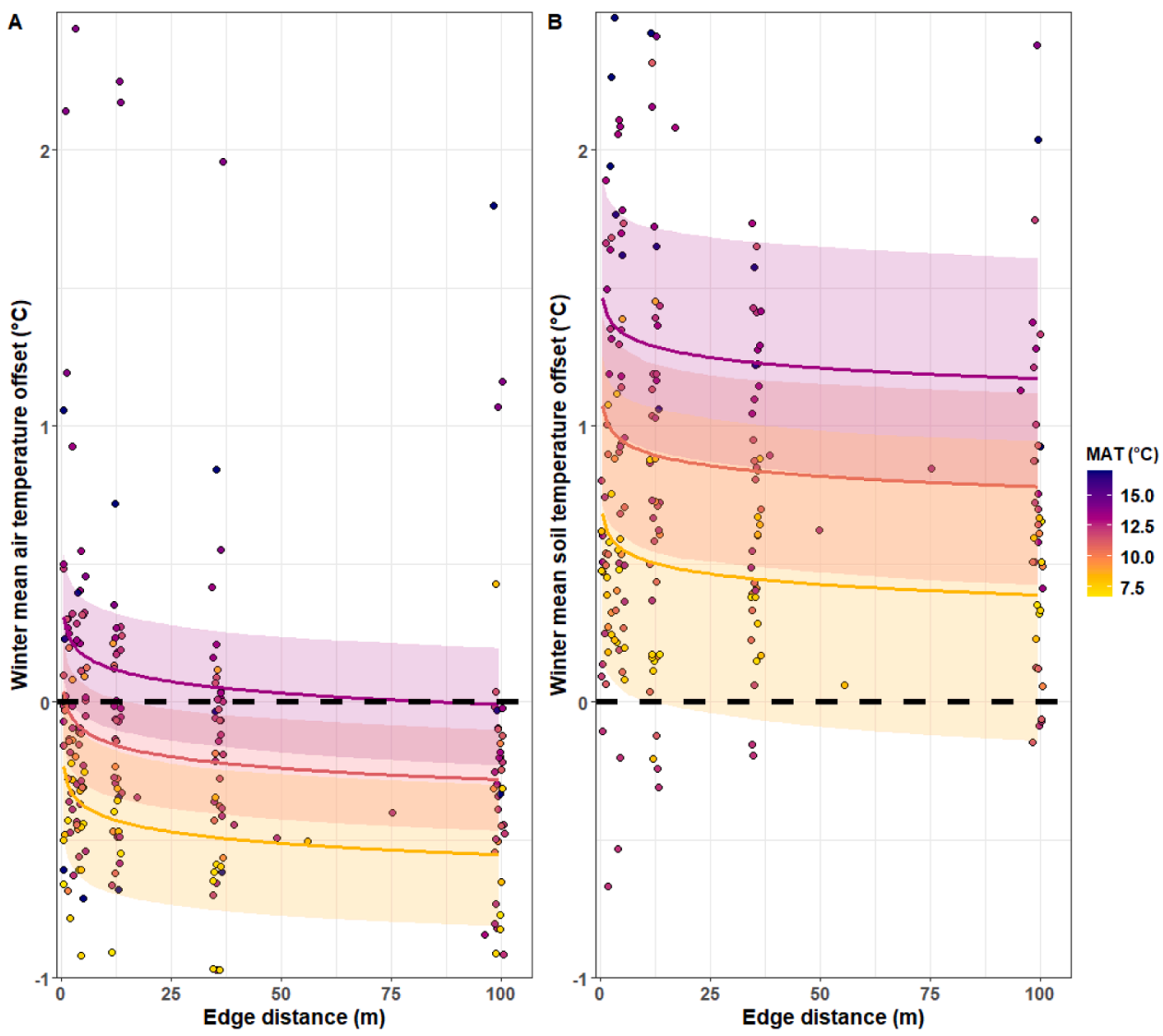

Fig. 4. Predictions of the mean air temperature offset ( ${ }^{\circ} \mathrm{C}$, panel A) and soil temperature offset ( ${ }^{\circ} \mathrm{C}$, panel B) during the winter (mean and $95 \%$ prediction intervals) as function of the distance to the edge $(\mathrm{m})$. The colours of the lines represent three distinct macroclimates (cold, intermediate and warm) within the studied macroclimate gradient. The dots represent the raw data points and their colour shows the mean annual macroclimate temperature outside the forest (MAT, ${ }^{\circ} \mathrm{C}$ ); a small amount of jittering was added along the $\mathrm{x}$-axis to improve clarity.

Table 2

Depth of edge influence (m) (i.e. distance up to which the temperature offset was significantly different from the offset detected in the forest interior at $99.5 \mathrm{~m}$ from the edge) of the different temperature metrics (all in ${ }^{\circ} \mathrm{C}$ ) during winter and summer.

\begin{tabular}{|c|c|c|c|}
\hline \multicolumn{2}{|c|}{ Temperature metric } & \multirow{2}{*}{$\begin{array}{l}\text { Depth of edge influence air temperature } \\
\text { Between } 12.5 \text { and } 36.5 \mathrm{~m}\end{array}$} & \multirow{2}{*}{$\begin{array}{l}\text { Depth of edge influence soil temperature } \\
\text { Between } 1.5 \text { and } 4.5 \mathrm{~m}\end{array}$} \\
\hline In summer & Minimum temperature offset & & \\
\hline & Mean temperature offset & Between 4.5 and $12.5 \mathrm{~m}$ & Between 1.5 and 4.5 m \\
\hline & Maximum temperature offset & Between 1.5 and $4.5 \mathrm{~m}$ & Between 1.5 and $4.5 \mathrm{~m}$ \\
\hline \multirow[t]{3}{*}{ In winter } & Minimum temperature offset & Between 1.5 and $4.5 \mathrm{~m}$ & No edge influence \\
\hline & Mean temperature offset & Between 12.5 and $36.5 \mathrm{~m}$ & Between 1.5 and $4.5 \mathrm{~m}$ \\
\hline & Maximum temperature offset & Between 12.5 and $36.5 \mathrm{~m}$ & Between 4.5 and $12.5 \mathrm{~m}$ \\
\hline
\end{tabular}

Table 3

The impact of local site characteristics (forest structure and composition, forest floor-biomass and soil texture) and regional landscape characteristics and macroclimate on the mean offset $\left({ }^{\circ} \mathrm{C}\right)$ of air and soil temperatures during summer and winter, and the evaporation. The effects for Tmin and Tmax can be found in the appendix (Supplementary table B3). The direction of the effect is shown with arrows and the significance is indicated with asterisks ${ }^{*}=p<0.05,{ }^{* *}=p<0.01, * * *=p<$ 0.001). MST = mean seasonal temperature. Explanatory variables without any significant effect were removed from the table.

\begin{tabular}{|c|c|c|c|c|c|}
\hline & $\begin{array}{l}\text { Summer air temperature } \\
\text { offset }\left({ }^{\circ} \mathrm{C}\right)\end{array}$ & $\begin{array}{l}\text { Summer soil temperature } \\
\text { offset }\left({ }^{\circ} \mathrm{C}\right)\end{array}$ & $\begin{array}{l}\text { Winter air temperature } \\
\text { offset }\left({ }^{\circ} \mathrm{C}\right)\end{array}$ & $\begin{array}{l}\text { Winter soil temperature } \\
\text { offset }\left({ }^{\circ} \mathrm{C}\right)\end{array}$ & $\begin{array}{l}\text { Evaporation (log- } \\
\text { transformed) (mm/year) }\end{array}$ \\
\hline Plant area index (-) & $\downarrow^{* * *}$ & $\downarrow^{* * *}$ & $\downarrow^{* * *}$ & $\downarrow^{* * *}$ & - \\
\hline Canopy height (m) & - & - & $\downarrow^{*}$ & - & - \\
\hline Shade casting ability (-) & $\downarrow^{* *}$ & - & - & - & $\downarrow^{*}$ \\
\hline Canopy closure (\%) & $\downarrow^{* * *}$ & $\downarrow^{*}$ & $\uparrow^{* * *}$ & - & $\downarrow * * *$ \\
\hline Basal area $\left(\mathrm{m}^{2} / \mathrm{ha}\right)$ & - & - & - & - & $\uparrow * *$ \\
\hline $\begin{array}{l}\text { Plant area index shrub layer } \\
(-)\end{array}$ & - & - & - & $\uparrow * * *$ & - \\
\hline $\begin{array}{l}\text { Forest-floor biomass (kg/ } \\
\mathrm{m}^{2} \text { ) }\end{array}$ & - & - & $\uparrow^{*}$ & $\uparrow^{* * * *}$ & - \\
\hline $\begin{array}{l}\text { MST macroclimate outside } \\
\text { forests }\left({ }^{\circ} \mathrm{C}\right)\end{array}$ & - & $\downarrow$ l*** & - & - & - \\
\hline Northness (-) & - & - & $\downarrow^{* *}$ & - & - \\
\hline Forest cover (\%) & - & - & $\downarrow^{* *}$ & - & - \\
\hline
\end{tabular}


a
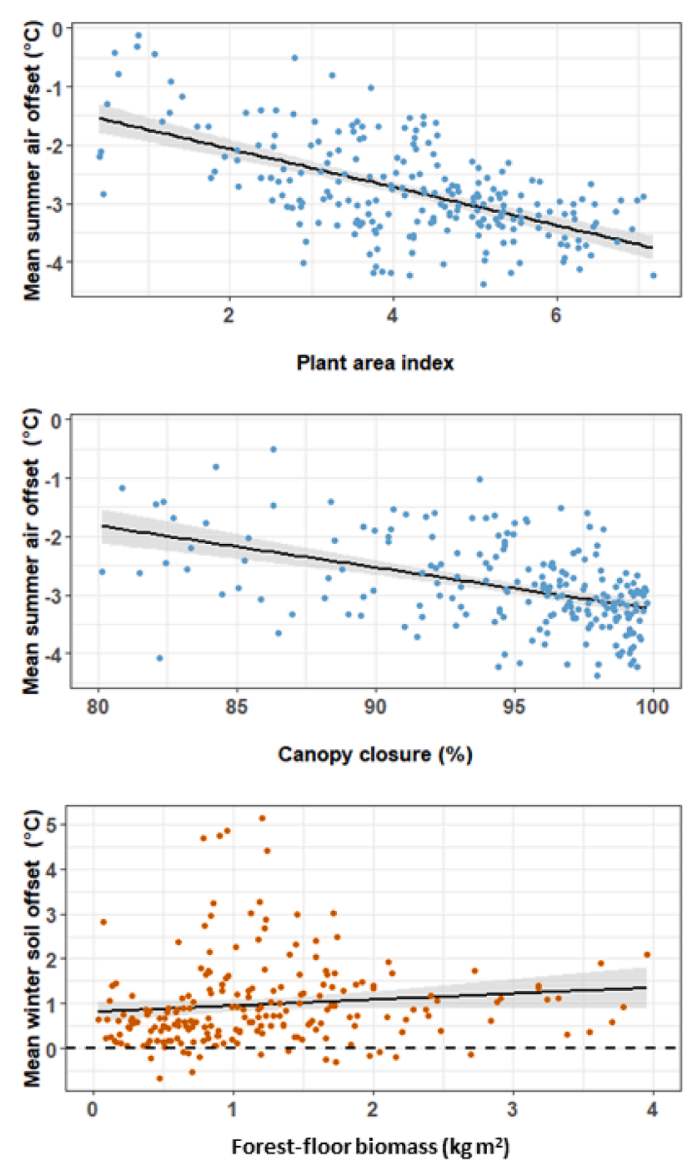

b

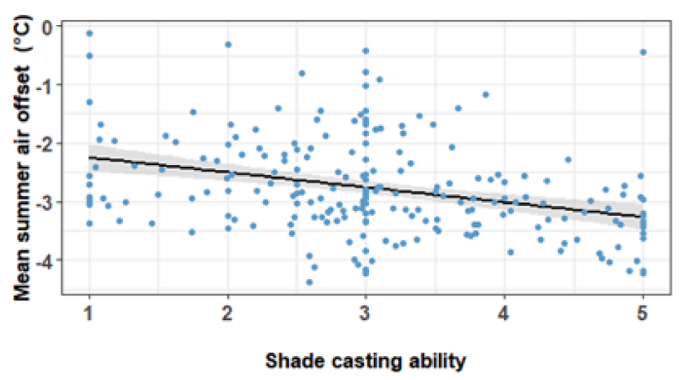

d

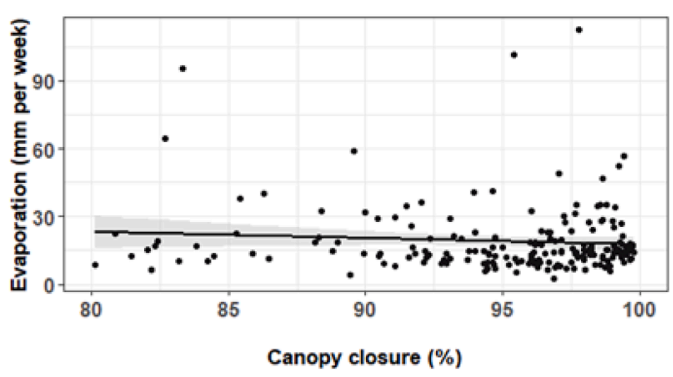

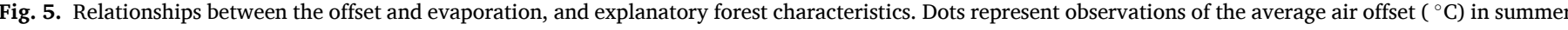

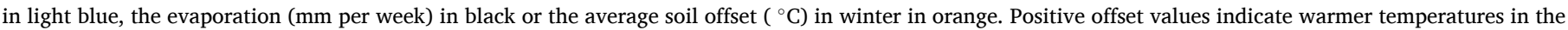

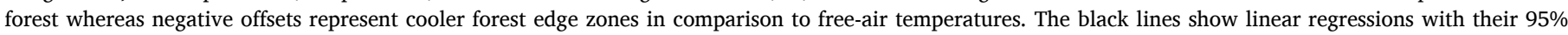
confidence intervals shaded in grey.

high shade casting ability (Fig. 5b). For soil summer temperatures, we also found a strong negative effect of the summer soil macroclimate on the mean and maximum soil temperature offsets in forests. The macroclimate was an important driver of the minimum soil summer offset as well. Minimum air temperature offsets, on the other hand were more positive in open forests and forests located in areas with warm summers, but decreased in forests with a dense shrub layer. In short, mainly forest structure, and for soil temperatures also the macroclimate, were important drivers of the summer offset. Likewise, forest structure was an important regulator of the evaporation in forest edge zones. Evaporation was higher in open forests (Fig. 5d) dominated by trees with a low shade casting ability (Table 3 ).

The plant area index remained an important driver of the winter offsets, though the importance of the different drivers shifted in this season (Table 3 and Supplementary Table B3). Other drivers such as slope, northness or canopy height were found to have a significant impact on the winter offset too. Finally, also the forest-floor litter and humus biomass played a key role in the establishment of a winter forest microclimate; a higher biomass in the humus and litter layer had an important positive effect on the mean and maximum offsets in the soil (i. e. more positive offset, Fig. 5e), and to a lesser extent in the air during the winter.

\section{Discussion}

\subsection{Microclimatic changes across forest edges}

Across Europe, we found that summer temperatures were generally more than $2{ }^{\circ} \mathrm{C}$ cooler inside forest edge zones. Maximum soil and air forest summer temperatures were on average cooler, whereas minimum summer temperatures were warmer in comparison to free-air temperatures. Altogether, forests were subject to a significant buffering (i.e. dampening of macroclimatic temperature variations (De Frenne et al., 2021)), or thus fewer extreme temperatures and a lower temperature variability during the summer (De Frenne et al., 2019; Zellweger et al., 2019). Moreover, we showed that summer air and soil temperatures in the forest interior experienced a stronger buffering of mean and warm ambient temperatures in comparison to forest edges. In addition to a cooling of warm temperatures also evaporation was reduced in the interior. Increasingly cooler temperatures and a higher humidity towards the forest interior are often observed patterns in forest patches which can be attributed to a diminution of direct solar radiation and changes in wind conditions (Matlack, 1993; Davies-Colley et al., 2000; Hylander, 2005; Schmidt et al., 2019). Indeed, temperature and humidity are strongly correlated and can be linked with steep edge-orientated light gradients in forest edge zones (Matlack, 1993; Chen et al., 1995; Davies-Colley et al., 2000; Kovács et al., 2017; Li et al., 2018). In addition, since minimum summer temperatures were higher inside the forest and increased towards the interior, also extreme summer temperatures were better buffered (i.e. macroclimatic fluctuations were reduced) in the interior compared to edges in our study.

During winter, we found a negative impact of edge distance on the offsets as well. Mean and maximum offsets dropped towards the interior, resulting in cooler forest interiors relative to open areas and edges. However, directly at the edge and especially in the soil, winter offsets were mainly positive. So, in winter, forest edge zones were often warmer 
than ambient air temperatures. Warmer temperatures in forests during winter and night have been observed before (Chen et al., 1995; Aussenac, 2000; Zellweger et al., 2019), but our results showed that this warming effect was mainly apparent in forest soils and near the edge. In the soil, positive offsets in winter might be due to the presence of an insulating layer of snow and/or litter (Bartlett, 2004; Graae et al., 2012; Fekete et al., 2016). Deeper snow or thicker litter layers might build up near forest edges. Snow build up can result from a higher canopy openness near the edge; or due to abrupt vegetation changes and the presence of shrubs windblown snow and leaves might be trapped near edges and buffer soil temperatures (Feeley, 2004; Vasconcelos and Luizão, 2004; Mellander et al., 2005; Myers-Smith et al., 2011). Secondly, warming near the edge could also be due to heating of the soil, and subsequently via a heat-flux the air above, due to more incoming solar radiation in leafless deciduous forests in winter and via lateral penetration at the forest edge (Chen et al., 1995; Davies-Colley et al., 2000).

\subsubsection{Macroclimate: temperatures outside forests also influence offsets}

We found that the macroclimate interacted with edge distance: MAT positively affected the edge-to-interior gradients in minimum, maximum and mean summer air temperature offset and, on the contrary, had a negative impact on the maximum soil temperature offset during winter. For summer air temperatures, the cooling of mean and maxima was strongest at the edge in warm regions but differences diminished towards the interior as the slope in offset was steeper in cold regions. Minimum summer air temperatures, on the other hand, were warmer in the interior and edge-to-interior gradients stronger at more southern latitudes. Forests in warm, southern European regions thus experienced the strongest reduction in temperature variability, especially in the forest interior. A stronger buffering in warmer macroclimates is a worldwide phenomenon related to, amongst others, seasonal effects, evapotranspiration and solar radiation inputs (De Frenne et al., 2019), showing that forests could form temporary local microclimatic refugia under globally rising temperatures and during heat waves. The main novelty here was the interaction with the distance to the forest edge and that differences in offsets between regions were already present directly at the forest edge. In winter, maximum soil temperatures were higher near the edge in warm regions whereas the edge-to-interior gradients were almost absent in cooler regions. We therefore hypothesize that warmer soil temperatures might be driven by heat accumulation in the soil near the edge, especially in warm regions, or the buffering effect of a snow cover in northern areas (Chen et al., 1995; Davies-Colley et al., 2000; Myers-Smith et al., 2011).

\subsubsection{Forest management}

Forest management also affected edge-to-interior patterns in the mean summer air offset (i.e. open forests generated only a low temperature offset near the edge but were characterized by steeper gradients in temperature). From the edge to interior, the offset in open forests increased from -2.1 to $-2.7{ }^{\circ} \mathrm{C}$. In dense forests nonetheless, temperatures were already strongly reduced at the edge with an average offset of $-2.8{ }^{\circ} \mathrm{C}$ and reached mean values of $-3.1{ }^{\circ} \mathrm{C}$ in the interior. The average offset in dense edges was similar to the average offset in open forest interiors. Dense forests were characterised by a steep temperature drop at the edge, which can be caused by abrupt gradients in vegetation structure between forest and adjacent land uses (Harper et al., 2005; Hofmeister et al., 2019). Dense edge zones are, however, strong thermal insulators and establish smoother and weaker edge-to-interior gradients, attributable to a higher complexity and a closed side-canopy protecting against incoming radiation (Matlack, 1993; Aussenac, 2000; Kovács et al., 2017; Ehbrecht et al., 2019). Steeper gradients, extending deeper towards the interior might manifest in intensively thinned forests due to the lack of a side-canopy and higher openness.

\subsubsection{Impact of edge-to-interior gradients}

Edge influences in air temperature offsets were detected up to $12.5 \mathrm{~m}$ from the edge. Soil temperature offsets were less sensitive to edge impact (significant differences up to only $4.5 \mathrm{~m}$ ) and stabilized at shorter distances as they are better buffered against temperature fluctuations, mainly depend on the direct effect of soil heating and are less impacted by ambient conditions (i.e. air-mixing and transfer of warm air from adjacent agricultural lands) (Chen et al., 1995; Davies-Colley et al., 2000; Li et al., 2018). Edge influences were somewhat smaller but in accordance with previous studies suggesting impacts up to approximately 40 - 50 m (Saunders et al., 1999; Davies-Colley et al., 2000; Schmidt et al., 2019). We consider our estimates as rather conservative since, firstly, edge influences can vary throughout the day and depend on weather conditions (Baker et al., 2014; Li et al., 2018). Second, edge influences might also reach deeper into the forest although the effect is not significant or might extend beyond the significant difference detected (i.e. lie somewhere between 12.5 and $36.5 \mathrm{~m}$, our next sample point). Third, it might be possible that microclimatic gradients are deeper than those investigated in our set-up (i.e. more than $100 \mathrm{~m}$ ); especially as our study design composes of southern forest edges in the northern hemisphere which are known to have deeper edge influences than north-orientated edges (Matlack, 1993; Chen et al., 1995; Hylander, 2005; Orczewska and Glista, 2005).

Considering an edge depth of $12.5 \mathrm{~m}$ and a total cumulative edge perimeter of roughly 9.4 billion $\mathrm{m}$ for European deciduous forests (Meeussen et al., 2021), at least 11.7 million ha of broadleaved forest in Europe are subject to edge influences in temperature. This is approximately $10 \%$ of the total area of broadleaved forests of the European continent and the result of severe fragmentation and land-use changes. As forests harbour the majority of terrestrial biodiversity (MEA, 2005), up to $80 \%$ of the plant species richness in temperate forests is associated with the understorey (Gilliam, 2007), forest fragmentation, apart from degradation and habitat loss, might form a threat to biodiversity. Our results indicated that edge microclimates differ considerably from interior microclimates and therefore will not support all organisms thriving in forest interiors. Due to their warm and open microclimate, edges are often dominated by warmth-loving and light-demanding generalists and can harbour a lower phylogenetic biodiversity than forest interiors (Honnay et al., 2002; Pellissier et al., 2013; Pfeifer et al., 2017; Govaert et al., 2020; De Pauw et al., 2021). Nevertheless, edges themselves can be valuable as well and management to maintain edges open might be important as they are biodiversity hotspots and vital habitat types for certain species, in particular those that depend on half-open woody sites and warmer microclimates (Duelli et al., 2002; De Smedt et al., 2019). Not only biodiversity will be impacted by edge influences; spatial fluctuations in temperature will affect ecosystem functioning and processes in edge zones such as litter decomposition or carbon drawdown (Riutta et al., 2012; Fekete et al., 2016; Schmidt et al., 2019; Meeussen et al., 2021).

\subsection{Drivers of forest edge microclimates}

Canopy cover and composition are known as key drivers of subcanopy temperatures (Matlack, 1993; Aussenac, 2000; De Frenne et al., 2013; Frey et al., 2016; Zellweger et al., 2019). We showed that vegetation structure and composition (i.e. shade casting ability) were important drivers of multiple offset metrics in forest edge zones as well. In general, a higher plant area index and canopy closure reduced both minimum and maximum air temperatures. Moreover, both explanatory variables might also drive the stronger offset in forest interiors since both plant area index and canopy closure increased from edge to interior (Meeussen et al., 2020). Forests with a high plant area index are usually composed of a dense and multi-layered canopy with a high foliage biomass (Gower et al., 1999; Kalácska et al., 2005). Dense canopies will intercept, absorb, reflect and emit radiation and subsequently buffer both heating and cooling of understorey temperatures (Aussenac, 2000; 
Li et al., 2018). Moreover, wind speed and patterns are altered under dense canopies, potentially causing an even stronger offset between micro- and macroclimate (Aussenac, 2000; Renaud et al., 2011). A complex and diverse stand structure, such as in old-growth forests or forests with a high diversity in tree sizes and species, has therefore been advised for the creation of stable forest microclimates (Frey et al., 2016; Kovács et al., 2017; Ehbrecht et al., 2019). Kovács et al. (2017) also suggested that, besides an additional shading effect, vertical complexity would contribute to microclimatic buffering by reducing the evaporation and increasing the humidity. We could, however, not find an impact of plant area index, or thus foliage density on the evaporation. A high canopy closure and shade casting ability did, however, reduce evaporation. This indicates that the penetration of direct radiation to the forest floor via gaps in the canopy might be a stronger predictor of the integrated air humidity, besides temperature, inside forests (Ehbrecht et al., 2019; Zellweger et al., 2019). Species composition further affected the thermal buffering capacity of forests: we found that both mean and maximum summer temperatures were lower in plots with more shade casting species (e.g. Fagus sylvatica) (Zellweger et al., 2019).

During the winter months, forest structural metrics were still found to drive the offset, however, also landscape characteristics and the forest-floor biomass were shown to play a vital role in regulating forest temperatures (Greiser et al., 2018; Zellweger et al., 2019). The impact of forest structure on the winter offset must be interpreted with caution as all structural metrics were determined during the growing season and some of them (e.g. canopy openness) are subject to seasonal variation in deciduous forests. However, even after leaf shedding, woody structural elements might still affect sub-canopy temperatures via lateral shading or by affecting wind patterns near the edge (Bramer et al., 2018; Greiser et al., 2018). On the other hand, our results supported the fact that this impact will be less pronounced in winter than during the growing season and therefore microtopography and other landscape characteristics can gain importance in regulating forest winter temperatures (Greiser et al., 2018; Zellweger et al., 2019). Winter soil and air temperatures were higher in edge zones with a thick forest-floor biomass. Changes in soil and forest floor colour will affect albedo and heat accumulation (Bonan, 2008). A thick litter layer might also form a protecting layer on top of the soil, moderating extreme temperatures and subsequently microbial processes and carbon, water and nutrient fluxes (Ogée and Brunet, 2002; Fekete et al., 2016; Kovács et al., 2017; Meeussen et al., 2021). During the winter, microtopography also affected the offset. Terrain features, besides vegetation structure, are known to determine local temperatures and thus also winter forest microclimates via, for instance, local variability in solar radiation, cold-air pooling in depressions or wind exposure (Frey et al., 2016; Aalto et al., 2017; Bramer et al., 2018; Davis et al., 2019).

\subsection{Impacts and forest management guidelines}

We demonstrated that edge influences cannot be ignored in microclimate studies, and that edge influences interacted with macroclimate and management. Our results further fill the knowledge gap on how forest edges affect microclimatic buffering on a continental scale, improve microclimatic mapping and contribute to future microclimatic analyses and the impact of global change on forest-dwelling organisms; all key questions related to microclimate research (De Frenne et al., 2021).

Land-use change, in conjunction with forest degradation and fragmentation are increasing the proportion of forest edges globally (Haddad et al., 2015; Riitters et al., 2016) and thus the impact of the physical environment on forests. In combination with warming worldwide, the potential for forest interiors to host and protect forest-dwelling organisms is threatened and therefore gaining importance (De Frenne et al., 2013, 2019; Frey et al., 2016). To maintain interior microclimates and their associated species, and to sustain short-term microclimatic refugia, fragmentation of large and old forests should thus be avoided. Also, large-scale management practices, homogenizing forest stands and creating interior edges and large canopy gaps, could better be replaced by small-scale cuts or even single tree-selection systems (Frey et al., 2016; Hofmeister et al., 2019). Not only management interventions might strongly increase sub-canopy temperatures but also disturbances such as droughts, storms and insect outbreaks are predicted to increase in abundance and severity (Seidl et al., 2017). Large-scale disturbances can damage forest canopies, reduce their insulating effect and therefore threaten forest interior habitats and cause a shift in species composition (Stevens et al., 2015). If cool and moist forest understories are desired to shelter forest interior specialists; smaller forests, harbouring important species, could be protected by a buffer zone (i.e. an additional forested edge area around the patch to maintain stable interior conditions in the forest patch) of at least $12.5 \mathrm{~m}$ deep, and via edge densification (i.e. creating a multi-layered edge with a low canopy openness and high foliage density) (Matlack, 1993; Li et al., 2018). Finally, also planting species near the edge which cast a deep shade on the forest floor (Zellweger et al., 2019) or aiming for a diverse mix of shrubs and shade tolerant species forming gradual and dense side canopies in forest edges (Mourelle et al., 2001; Niinemets, 2010; Jucker et al., 2015), might ameliorate microclimatic conditions and buffer climate-change impacts in forests. To end, we note that there are many edge-related species which do not prefer cool and humid forest microclimates. Highly-structured forest edge zones, forming a gradual transition between forest and adjacent lands, are important habitats themselves for many species (e.g., plants, butterflies, birds and insects) (Duelli et al., 2002; Lindgren et al., 2018). Moreover, it should be kept in mind that also several typical forest herbs can benefit from temporary higher light availability after natural disturbances and local gaps resulting from natural forest succession or management interventions (Hilmers et al., 2018).

\section{Declaration of Competing Interest}

The authors declare that they have no known competing financial interests or personal relationships that could have appeared to influence the work reported in this paper.

\section{Acknowledgements}

We thank Evy Ampoorter, Alicja Barć, Haben Blondeel, Filip and Kris Ceunen, Robbe De Beelde, Emiel De Lombaerde, Bente J. Graae, Kent Hansson, Lionel Hertzog, Szymon Kuś, Dries Landuyt, Iga Lewin, Pierre Lhoir, Sruthi M. Krishna Moorthy, Audrey Peiffer, Michael Perring, Mia Vedel Sørensen, Matteo Tolosano, Sanne Van Den Berge and Lotte Van Nevel for providing support during the fieldwork. Finally, we are grateful for the help of Luc Willems and Greet De bruyn for the chemical analyses and Pieter Vermeir and Abdulwahhab Ghrairi for the texture analysis.

\section{Data availability statement}

Data related to this manuscript are available on Figshare: https ://doi.org/10.6084/m9.figshare.16870759.

\section{Funding information}

This work was supported by the European Research Council [ERC Starting Grant FORMICA no. 757833, 2018] (http://www.formica. ugent.be) and the FWO Scientific Research Network FLEUR (www. fleur.ugent.be). Sanne Govaert was supported by the Research Foundation Flanders [FWO project no. G0H1517N]. Thomas Vanneste received funding from the Special Research Fund (BOF) from Ghent University [no. 01N02817]. Kim Calders was funded by the European Union's Horizon 2020 Research and Innovation Programme under the Marie Sklodowska-Curie grant agreement [no. 835398]. Florian 
Zellweger received funding from the Swiss National Science Foundation [no. 193645].

\section{References}

Aalto, J., Riihimäki, H., Meineri, E., Hylander, K., Luoto, M., 2017. Revealing topoclimatic heterogeneity using meteorological station data. Int. J. Climatol. 37, 544-556. https://doi.org/10.1002/joc.5020.

Aussenac, G., 2000. Interactions between forest stands and microclimate: ecophysiological aspects and consequences for silviculture. Ann. For. Sci. https:// doi.org/10.1051/forest:2000119.

Baker, T.P., Jordan, G.J., Steel, E.A., Fountain-Jones, N.M., Wardlaw, T.J., Baker, S.C., 2014. Microclimate through space and time: microclimatic variation at the edge of regeneration forests over daily, yearly and decadal time scales. For. Ecol. Manage. 334 https://doi.org/10.1016/j.foreco.2014.09.008.

Bartlett, M.G., 2004. Snow and the ground temperature record of climate change. J. Geophys. Res. 109, F04008. https://doi.org/10.1029/2004JF000224.

Bates, D., Mächler, M., Bolker, B., Walker, S., 2015. Fitting linear mixed-effects models using lme4. J. Stat. Softw. 67, 1-48. https://doi.org/10.18637/jss.v067.i01.

Bertrand, R., Lenoir, J., Piedallu, C., Riofrío-Dillon, G., de Ruffray, P., Vidal, C., Pierrat, J.-.C., Gégout, J.-.C., 2011. Changes in plant community composition lag behind climate warming in lowland forests. Nature 479, 517-520. https://doi.org/ 10.1038 /nature10548.

Bonan, G.B., 2008. Forests and climate change: forcings, feedbacks, and the climate benefits of forests. Science 80. https://doi.org/10.1126/science.1155121.

Bramer, I., Anderson, B.J., Bennie, J., Bladon, A.J., De Frenne, P., Hemming, D., Hill, R. A., Kearney, M.R., Körner, C., Korstjens, A.H., Lenoir, J., Maclean, I.M.D., Marsh, C D., Morecroft, M.D., Ohlemüller, R., Slater, H.D., Suggitt, A.J., Zellweger, F., Gillingham, P.K., 2018. Advances in monitoring and modelling climate at ecologically relevant scales. Advances in Ecological Research. Academic Press Inc., pp. 101-161. https://doi.org/10.1016/bs.aecr.2017.12.005

Calders, K., Adams, J., Armston, J., Bartholomeus, H., Bauwens, S., Bentley, L.P., Chave, J., Danson, F.M., Demol, M., Disney, M., Gaulton, R., Krishna Moorthy, S.M., Levick, S.R., Saarinen, N., Schaaf, C., Stovall, A., Terryn, L., Wilkes, P., Verbeeck, H. 2020. Terrestrial laser scanning in forest ecology: expanding the horizon. Remote Sens. Environ. https://doi.org/10.1016/j.rse.2020.112102.

Chen, J., Franklin, J.F., Spies, T.A., 1995. Growing-season microclimatic gradients from clearcut edges into old-growth Douglas-fir forests. Ecol. Appl. 5, 74-86. https://doi. org/10.2307/1942053.

Chen, J., Saunders, S.C., Crow, T.R., Naiman, R.J., Brosofske, K.D., Mroz, G.D., Brookshire, B.L., Franklin, J.F., 1999. Microclimate in forest ecosystem and landscape ecology. Bioscience 49, 288-297. https://doi.org/10.2307/1313612.

Chen, Y., Liu, Y., Zhang, J., Yang, W., He, R., Deng, C., 2018. Microclimate exerts greater control over litter decomposition and enzyme activity than litter quality in an alpine forest-tundra ecotone. Sci. Rep. 8, 1-13. 10.1038/s41598-018-33186-4.

Davies-Colley, R.J., Payne, G.W., Van Elswijk, M., 2000. Microclimate gradients across a forest edge. NZJ. Ecol. 24, 111-121.

Davis, F.W., Synes, N.W., Fricker, G.A., McCullough, I.M., Serra-Diaz, J.M., Franklin, J. Flint, A.L., 2019. LiDAR-derived topography and forest structure predict fine-scale variation in daily surface temperatures in oak savanna and conifer forest landscapes. Agric. For. Meteorol. 269-270, 192-202. 10.1016/J.AGRFORMET.2019.02.015.

De Frenne, P., Lenoir, J., Luoto, M., Scheffers, B.R., Zellweger, F., Aalto, J., Ashcroft, M. B., Christiansen, D.M., Decocq, G., De Pauw, K., Govaert, S., Greiser, C., Gril, E., Hampe, A., Jucker, T., Klinges, D.H., Koelemeijer, I.A., Lembrechts, J.J., Marrec, R., Meeussen, C., Ogée, J., Tyystjärvi, V., Vangansbeke, P., Hylander, K., 2021. Forest microclimates and climate change: importance, drivers and future research agenda. Glob. Chang. Biol. Gcb. 15569. 10.1111/gcb.15569.

De Frenne, P., Rodríguez-Sánchez, F., Coomes, D.A., Baeten, L., Verstraeten, G., Vellen, M., Bernhardt-Römermann, M., Brown, C.D., Brunet, J., Cornelis, J., Decocq, G.M., Dierschke, H., Eriksson, O., Gilliam, F.S., Hédl, R., Heinken, T., Hermy, M., Hommel, P., Jenkins, M.A., Kelly, D.L., Kirby, K.J., Mitchell, F.J.G., Naaf, T., Newman, M., Peterken, G., Petř́k, P., Schultz, J., Sonnier, G., Van Calster, H., Waller, D.M., Walther, G.R., White, P.S., Woods, K.D., Wulf, M., Graae, B.J., Verheyen, K., 2013. Microclimate moderates plant responses to macroclimate warming. Proc. Natl. Acad. Sci. USA 110, 18561-18565. 10.1073/pnas.1311190110.

De Frenne, P., Rodríguez-Sánchez, F., De Schrijver, A., Coomes, D.A., Hermy, M., Vangansbeke, P., Verheyen, K., 2015. Light accelerates plant responses to warming. Nat. Plants, 1(9), 1-3. 10.1038/NPLANTS.2015.110.

De Frenne, P., Zellweger, F., Rodríguez-Sánchez, F., Scheffers, B.R., Hylander, K., Luoto, M., Vellend, M., Verheyen, K., Lenoir, J., 2019. Global buffering of temperatures under forest canopies. Nat. Ecol. Evol. 3, 744-749. 10.1038/s41559-019-0842-1.

De Pauw, K., Meeussen, C., Govaert, S., Sanczuk, P., Vanneste, T., BernhardtRömermann, M., Bollmann, K., Brunet, J., Calders, K., Cousins, S., Diekmann, M., Hedwall, P., Iacopetti, G., Lenoir, J., Lindmo, S., Orczewska, A., Ponette, Q., Plue, J., Selvi, F., Spicher, F., Verbeeck, H., Vermeir, P., Zellweger, F., Verheyen, K., Vangansbeke, P., De Frenne, P., 2021. Taxonomic, phylogenetic and functional diversity of understorey plants respond differently to environmental conditions in European forest edges. J. Ecol. 10.1111/1365-2745.13671.

De Smedt, P., Baeten, L., Proesmans, W., Van de Poel, S., Van Keer, J., Giffard, B., Martin, L., Vanhulle, R., Brunet, J., Cousins, S.A.O., Decocq, G., Deconchat, M., Diekmann, M., Gallet-Moron, E., Le Roux, V., Liira, J., Valdés, A., Wulf, M., Andrieu, E., Hermy, M., Bonte, D., Verheyen, K., 2019. Strength of forest edge effects on litter-dwelling macro-arthropods across Europe is influenced by forest age and edge properties. Divers. Distrib. 25, 963-974. 10.1111/ddi.12909.
Duelli, P., Obrist, M.K., \& Fluckiger, P.F., 2002. Forest edges are biodiversity hotspots-also for Neuroptera. Acta Zool. Acad. Sci. Hung., 48(Suppl 2), $75-87$.

Dutta, B., Grant, B.B., Congreves, K.A., Smith, W.N., Wagner-Riddle, C., VanderZaag, A. C., Tenuta, M., Desjardins, R.L., 2018. Characterising effects of management practices, snow cover, and soil texture on soil temperature: model development in DNDC. Biosyst. Eng. 168, 54-72. 10.1016/j.biosystemseng.2017.02.001.

Ehbrecht, M., Schall, P., Ammer, C., Fischer, M., Seidel, D., 2019. Effects of structural heterogeneity on the diurnal temperature range in temperate forest ecosystems. For. Ecol. Manage. 432, 860-867. 10.1016/J.FORECO.2018.10.008.

EU-DEM. (2018). EU-digital elevation model (DEM). Version 1.1. Retrieved from https:// land.coper nicus.eu/imagery-in-situ/eu-dem/eu-dem-v1.1.

Feeley, K.J., 2004. The effects of forest fragmentation and increased edge exposure on leaf litter accumulation. J. Trop. Ecol. 20, 709-712. 10.1017/S0266467404001828.

Fekete, I., Varga, C., Biró, B., Tóth, J.A., Várbíró, G., Lajtha, K., Szabó, G., Kotroczó, Z., 2016. The effects of litter production and litter depth on soil microclimate in a central european deciduous forest. Plant Soil 398, 291-300. 10.1007/s11104-01 5-2664-5.

Frey, S.J.K., Hadley, A.S., Johnson, S.L., Schulze, M., Jones, J.A., Betts, M.G., 2016. Spatial models reveal the microclimatic buffering capacity of old-growth forests. Sci. Adv. 2, e1501392. 10.1126/sciadv.1501392.

Geiger, R., Aron, R.H., Todhunter, P., 2009. The Climate Near the Ground. Rowman \& Littlefield.

Gilliam, F.S., 2007. The ecological significance of the herbaceous layer in temperate forest ecosystems. Bioscience, 57(10), 845-858. 10.1641/B571007.

Govaert, S., Meeussen, C., Vanneste, T., Bollmann, K., Brunet, J., Cousins, S.A.O., Diekmann, M., Graae, B.J., Hedwall, P.-.O., Heinken, T., Iacopetti, G., Lenoir, J., Lindmo, S., Orczewska, A., Perring, M.P., Ponette, Q., Plue, J., Selvi, F., Spicher, F., Tolosano, M., Vermeir, P., Zellweger, F., Verheyen, K., Vangansbeke, P., De Frenne, P., 2020. Edge influence on understorey plant communities depends on forest management. J. Veg. Sci. 31. 10.1111/jvs.12844.

Gower, S.T., Kucharik, C.J., Norman, J.M., 1999. Direct and indirect estimation of leaf area index, f(APAR), and net primary production of terrestrial ecosystems. Remote Sens. Environ. 70, 29-51. 10.1016/S0034-4257(99)00056-5.

Graae, B.J., De Frenne, P., Kolb, A., Brunet, J., Chabrerie, O., Verheyen, K., Pepin, N., Heinken, T., Zobel, M., Shevtsova, A., Nijs, I., Milbau, A., 2012. On the use of weather data in ecological studies along altitudinal and latitudinal gradients. Oikos 121, 3-19. 10.1111/j.1600-0706.2011.19694.x.

Greiser, C., Meineri, E., Luoto, M., Ehrlén, J., Hylander, K., 2018. Monthly microclimate models in a managed boreal forest landscape. Agric. For. Meteorol. 250-251, 147-158. 10.1016/J.AGRFORMET.2017.12.252.

Haddad, N.M., Brudvig, L.A., Clobert, J., Davies, K.F., Gonzalez, A., Holt, R.D., Lovejoy, T.E., Sexton, J.O., Austin, M.P., Collins, C.D., Cook, W.M., Damschen, E.I., Ewers, R. M., Foster, B.L., Jenkins, C.N., King, A.J., Laurance, W.F., Levey, D.J., Margules, C. R., Melbourne, B.A., Nicholls, A.O., Orrock, J.L., Song, D.-.X., Townshend, J.R. 2015. Habitat fragmentation and its lasting impact on Earth's ecosystems. Sci. Adv. 1, e1500052. 10.1126/sciadv.1500052.

Hansen, M.C., Potapov, P.V., Moore, R., Hancher, M., Turubanova, S.A., Tyukavina, A., Thau, D., Stehman, S.V., Goetz S.J., Loveland, T.R., Kommareddy, A., Egorov, A., Chini, L., Justice, C.O., Townshend, J.R.G., 2013. High-resolution global maps of 21st-century forest cover change. Science, 342(6160), 850-853. 10.1126/science.1 244693.

Harper, K.A., Macdonald, S.E., Burton, P.J., Chen, J., Brosofske, K.D., Saunders, S.C., Euskirchen, E.S., Roberts, D., Jaiteh, M.S., Esseen, .P.-A., 2005. Edge influence on forest structure and composition in fragmented landscapes. Conserv. Biol. 19, 768-782. 10.1111/j.1523-1739.2005.00045.x.

Hilmers, T., Friess, N., Bässler, C., Heurich, M., Brandl, R., Pretzsch, H., Seidl, R., Müller, J., 2018. Biodiversity along temperate forest succession. J. Appl. Ecol. 55, 2756-2766. 10.1111/1365-2664.13238.

Hofmeister, J., Hošek, J., Brabec, M., Střalková, R., Mýlová, P., Bouda, M., Pettit, J.L., Rydval, M., Svoboda, M., 2019. Microclimate edge effect in small fragments of temperate forests in the context of climate change. For. Ecol. Manage. 448, 48-56. 10.1016/j.foreco.2019.05.069.

Honnay, O., Verheyen, K., Hermy, M., 2002. Permeability of ancient forest edges for weedy plant species invasion. For. Ecol. Manage. 161, 109-122. 10.1016/S0378-11 27(01)00490-X.

Hothorn, T., Bretz, F., Westfall, P., 2008. Simultaneous inference in general parametric models. Biometrical J. 10.1002/bimj.200810425.

Hylander, K., 2005. Aspect modifies the magnitude of edge effects on bryophyte growth in boreal forests. J. Appl. Ecol. 42, 518-525. 10.1111/j.1365-2664.2005.01033.x.

International Civil Aviation Organization, 1993. Manual of the ICAO Standard atmosphere: Extended to 80 Kilometres (262 500 Feet), 3rd ed. International Civil Aviation Organization, Montreal, Quebec.

IPCC, 2018. Summary for Policymakers. In: Global Warming of $1.5^{\circ} \mathrm{C}$. An IPCC Special Report On the Impacts of Global Warming of $1.5^{\circ} \mathrm{C}$ Above Pre-Industrial Levels and Related Global Greenhouse Gas Emission pathways, in the Context of Strengthening the Global Response to the Threat of Climate change, Sustainable development, and Efforts to Eradicate Poverty Masson-Delmotte, V., P. Zhai, H.-O. Pörtner, D. Roberts, J. Skea, P.R. Shukla et al. (eds.). World Meteorological Organization, Geneva, Switzerland, $32 \mathrm{pp}$.

ISO 11277, 2009. Soil Quality - Determination of Particle Size Distribution in Mineral Soil Material - Method by Sieving and Sedimentation ISO, Geneva.

Jucker, T., Bouriaud, O., Coomes, D.A., 2015. Crown plasticity enables trees to optimize canopy packing in mixed-species forests. Funct. Ecol. 29, 1078-1086. 10.1111 /1365-2435.12428. 
Kalácska, M., Calvo-Alvarado, J.C., Sánchez-Azofeifa, G.A., 2005. Calibration and assessment of seasonal changes in leaf area index of a tropical dry forest in different stages of succession. Tree Physiol. 25, 733-744. 10.1093/TREEPHYS/25.6.733.

Karger, D.N., Conrad, O., Böhner, J., Kawohl, T., Kreft, H., Soria-Auza, R.W., Zimmermann, N.E., Linder, H.P., Kessler, M., 2017. Climatologies at high resolution for the earth's land surface areas. Sci. Data 4, 170122. 10.1038/sdata.2017.122.

Kovács, B., Tinya, F., Ódor, P., 2017. Stand structural drivers of microclimate in mature temperate mixed forests. Agric. For. Meteorol. 234-235, 11-21. 10.1016/j.ag rformet.2016.11.268.

Kuznetsova, A., Brockhoff, P.B., Christensen, R.H.B., 2017. lmerTest package: tests in linear mixed effects models. J. Stat. Softw. 82, 1-26. 10.18637/jss.v082.i13.

Lembrechts, J.J., Lenoir, J., 2019. Microclimatic conditions anywhere at any time! Glob. Chang. Biol. 10.1111/gcb.14942.

Li, Y., Kang, W., Han, Y., Song, Y., 2018. Spatial and temporal patterns of microclimates at an urban forest edge and their management implications. Environ. Monit. Assess. 190, 93. 10.1007/s10661-017-6430-4.

Lindgren, J., Kimberley, A., Cousins, S.A.O., 2018. The complexity of forest borders determines the understorey vegetation. Appl. Veg. Sci. 21, 85-93. 10.1111/avsc.1 2344.

Magura, T., 2002. Carabids and forest edge: spatial pattern and edge effect. For. Ecol. Manage. 157, 23-37. 10.1016/S0378-1127(00)00654-X.

Matlack, G.R., 1993. Microenvironment variation within and among forest edge sites in the eastern United States. Biol. Conserv. 66, 185-194. 10.1016/0006-3207(93) 90004-K.

MEA, 2005. Millennium Ecosystem Assessment. Ecosystems and Human well-being: Biodiversity synthesis. Washington, DC: Millennium Ecosystem Assessment.

Meeussen, C., Govaert, S., Vanneste, T., Calders, K., Bollmann, K., Brunet, J., Cousins, S A.O., Diekmann, M., Graae, B.J., Hedwall, P.O., Krishna Moorthy, S.M., Iacopetti, G., Lenoir, J., Lindmo, S., Orczewska, A., Ponette, Q., Plue, J., Selvi, F., Spicher, F., Tolosano, M., Verbeeck, H., Verheyen, K., Vangansbeke, P., De Frenne, P., 2020. Structural variation of forest edges across Europe. For. Ecol. Manage. 462, 117929 10.1016/j.foreco.2020.117929.

Meeussen, C., Govaert, S., Vanneste, T., Haesen, S., Van Meerbeek, K., Bollmann, K., Brunet, J., Calders, K., Cousins, S.A.O., Diekmann, M., Graae, B.J., Iacopetti, G., Lenoir, J., Orczewska, A., Ponette, Q., Plue, J., Selvi, F., Spicher, F., Sørensen, M.V., Verbeeck, H., Vermeir, P., Verheyen, K., Vangansbeke, P., De Frenne, P., 2021. Drivers of carbon stocks in forest edges across Europe. Sci. Total Environ. 759, 143497. 10.1016/j.scitotenv.2020.143497.

Mellander, P.E., Laudon, H., Bishop, K., 2005. Modelling variability of snow depths and soil temperatures in Scots pine stands, in: Agricultural and Forest Meteorology. Elsevier, pp. 109-118. 10.1016/j.agrformet.2005.08.008.

Mourelle, C., Kellman, M., Kwon, L., 2001. Light occlusion at forest edges: an analysis of tree architectural characteristics. For. Ecol. Manage. 154, 179-192. 10.101 6/S0378-1127(00)00624-1.

Muñoz Sabater, J., 2019. ERA5-Land Hourly Data from 1981 to Present Copernicus Climate Change Service (C3S) Climate Data Store (CDS). (Accessed on 23-02-2021), $10.24381 /$ cds.e2161bac.

Murcia, C., 1995. Edge effects in fragmented forests: implications for conservation. Trends Ecol. Evol. 10, 58-62. 10.1016/S0169-5347(00)88977-6.

Myers-Smith, I.H., Forbes, B.C., Wilmking, M., Hallinger, M., Lantz, T., Blok, D., Tape, K. D., Macias-Fauria, M., Sass-Klaassen, U., Lévesque, E., Boudrea, S., Ropars, P. Hermanutz, L., Trant, A., Siegwart Collier, L., Weijers, S., Rozema, J., Rayback, S.A., Schmidt, N.M., Schaepman-Strub, G., Wipf, S., Rixen, C., Ménard, C.B., Venn, S., Goetz, S., Andreu-Hayles, L., Elmendorf, S., Ravolainen, V., Welker, J., Grogan, P., Epstein, H.E., Hik, D.S., 2011. Shrub expansion in tundra ecosystems: dynamics, impacts and research priorities. Environ. Res. Lett., 6(4), 045509.

Niinemets, Ü., 2010. A review of light interception in plant stands from leaf to canopy in different plant functional types and in species with varying shade tolerance. Ecol. Res. 25, 693-714. 10.1007/s11284-010-0712-4.

Ogée, J., Brunet, Y., 2002. A forest floor model for heat and moisture including a litter layer. J. Hydrol. 255, 212-233. 10.1016/S0022-1694(01)00515-7.

Orczewska, A., Glista, A., 2005. Floristic analysis of the two woodland-meadow ecotones differing in orientation of the forest edge. Polish J. Ecol. 53, 365-382.

Papaioannou, G., Vouraki, K., Kerkides, P., 1996. Piche evaporimeter data as a substitute for Penman equation's aerodynamic term. Agric. For. Meteorol. 82, 83-92.

Paul, K.I., Polglase, P.J., Smethurst, P.J., O'Connell, A.M., Carlyle, C.J., Khanna, P.K., 2004. Soil temperature under forests: a simple model for predicting soil temperature under a range of forest types. Agric. For. Meteorol. 121, 167-182. 10.1016/j.ag rformet.2003.08.030.

Pellissier, V., Bergès, L., Nedeltcheva, T., Schmitt, M.-.C., Avon, C., Cluzeau, C., Dupouey, J.L., 2013. Understorey plant species show long-range spatial patterns in forest patches according to distance-to-edge. J. Veg. Sci. 24, 9-24. 10.1111/j.1654-1103. 2012.01435.x.

Pfeifer, M., Lefebvre, V., Peres, C.A., Banks-Leite, C., Wearn, O.R., Marsh, C.J., Butchart, S.H.M., Arroyo-Rodríguez, V., Barlow, J., Cerezo, A., Cisneros, L., D'Cruze, N., Faria, D., Hadley, A., Harris, S.M., Klingbeil, B.T., Kormann, U., Lens, L., Medina-Rangel, G.
F., Morante-Filho, J.C., Olivier, P., Peters, S.L., Pidgeon, A., Ribeiro, D.B., Scherber, C., Schneider-Maunoury, L., Struebig, M., Urbina-Cardona, N., Watling, J.I., Willig, M.R., Wood, E.M., Ewers, R.M., 2017. Creation of forest edges has a global impact on forest vertebrates. Nature 551, 187-191. 10.1038/nature24457.

R Core Team, 2020. R: A Language and Environment For Statistical Computing. R Foundation for Statistical Computing. Austria. URL, Vienna https://www.R-project. org/.

Remy, E., Wuyts, K., Boeckx, P., Ginzburg, S., Gundersen, P., Demey, A., Van Den Bulcke, J., Van Acker, J., Verheyen, K., 2016. Strong gradients in nitrogen and carbon stocks at temperate forest edges. For. Ecol. Manage. 376, 45-58. 10.1016/j.foreco.2016.0 5.040 .

Renaud, V., Innes, J.L., Dobbertin, M., Rebetez, M., 2011. Comparison between open-site and below-canopy climatic conditions in Switzerland for different types of forests over 10 years (1998-2007). Theor. Appl. Climatol. 105, 119-127. 10.1007/s0070 4-010-0361-0.

Ries, L., Fletcher, R.J., Battin, J., Sisk, T.D., 2004. Ecological responses to habitat edges: mechanisms, models, and variability explained. Annu. Rev. Ecol. Evol. Syst. 35, 491-522. 10.1146/annurev.ecolsys.35.112202.130148.

Riitters, K., Wickham, J., Costanza, J.K., Vogt, P., 2016. A global evaluation of forest interior area dynamics using tree cover data from 2000 to 2012. Landsc. Ecol. 31, 137-148. 10.1007/s10980-015-0270-9.

Riutta, T., Slade, E.M., Bebber, D.P., Taylor, M.E., Malhi, Y., Riordan, P., Macdonald, D. W., Morecroft, M.D., 2012. Experimental evidence for the interacting effects of forest edge, moisture and soil macrofauna on leaf litter decomposition. Soil Biol. Biochem. 49, 124-131. 10.1016/j.soilbio.2012.02.028.

Sanczuk, P., Govaert, S., Meeussen, C., De Pauw, K., Vanneste, T., Depauw, L., Moreira, X., Schoelynck, J., De Boevre, M., De Saeger, S., Bollmann, K., Brunet, J., Cousins, S. A.O., Plue, J., Diekmann, M., Graae, B.J., Hedwall, P., Iacopetti, G., Lenoir, J., Orczewska, A., Ponette, Q., Selvi, F., Spicher, F., Vermeir, P., Calders, K., Verbeeck, H., Verheyen, K., Vangansbeke, P., De Frenne, P., 2021. Small scale environmental variation modulates plant defence syndromes of understorey plants in deciduous forests of Eur. Global Ecol. Biogeogr., 30(1), 205-219. 10.1111/geb.13216.

Saunders, S.C., Chen, J., Drummer, T.D., Crow, T.R., 1999. Modeling temperature gradients across edges over time in a managed landscape. For. Ecol. Manage. 117, 17-31. 10.1016/S0378-1127(98)00468-X.

Schmidt, M., Jochheim, H., Kersebaum, K.-.C., Lischeid, G., Nendel, C., 2017. Gradients of microclimate, carbon and nitrogen in transition zones of fragmented landscapes-a review. Agric. For. Meteorol. 232, 659-671. 10.1016/J.AGRFORMET.2016.10.022.

Schmidt, M., Lischeid, G., Nendel, C., 2019. Microclimate and matter dynamics in transition zones of forest to arable land. Agric. For. Meteorol. 268, 1-10. 10.1016/j. agrformet.2019.01.001.

Seidl, R., Thom, D., Kautz, M., Martin-Benito, D., Peltoniemi, M., Vacchiano, G., Wild, J., Ascoli, D., Petr, M., Honkaniemi, J., Lexer, M.J., Trotsiuk, V., Mairota, P., Svoboda, M., Fabrika, M., Nagel, T.A., Reyer, C.P.O., 2017. Forest disturbances under climate change. Nat. Clim. Chang. 10.1038/nclimate3303.

Stevens, J.T., Safford, H.D., Harrison, S., Latimer, A.M., 2015. Forest disturbance accelerates thermophilization of understory plant communities. J. Ecol. 103, 1253-1263. 10.1111/1365-2745.12426.

Vasconcelos, H.L., Luizão, F.J., 2004. Litter production and litter nutrient concentrations in a fragmented amazonian landscape. Ecol. Appl. 14, 884-892. 10.1890/03-5093.

Verheyen, K., Baeten, L., De Frenne, P., Bernhardt-Römermann, M., Brunet, J., Cornelis, J., Decocq, G., Dierschke, H., Eriksson, O., Hédl, R., Heinken, T., Hermy, M., Hommel, P., Kirby, K., Naaf, T., Peterken, G., Petřík, P., Pfadenhauer, J., Van Calster, H., Walther, G.R., Wulf, M., Verstraeten, G., 2012. Driving factors behind the eutrophication signal in understorey plant communities of deciduous temperate forests. J. Ecol. 100, 352-365. 10.1111/j.1365-2745.2011.01928.x.

Young, A., Mitchell, N., 1994. Microclimate and vegetation edge effects in a fragmented podocarp-broadleaf forest in New Zealand. Biol. Conserv. 67, 63-72. 10.101 6/0006-3207(94)90010-8.

Zellweger, F., Coomes, D., Lenoir, J., Depauw, L., Maes, S.L., Wulf, M., Kirby, K.J., Brunet, J., Kopecký, M., Máliš, F., Schmidt, W., Heinrichs, S., den Ouden, J., Jaroszewicz, B., Buyse, G., Spicher, F., Verheyen, K., De Frenne, P., 2019. Seasonal drivers of understorey temperature buffering in temperate deciduous forests across Europe. Glob. Ecol. Biogeogr. 28, 1774-1786. 10.1111/geb.12991.

Zellweger, F., de Frenne, P., Lenoir, J., Vangansbeke, P., Verheyen, K., BernhardtRömermann, M., Baeten, L., Hédl, R., Berki, I., Brunet, J., van Calster, H., Chudomelová, M., Decocq, G., Dirnböck, T., Durak, T., Heinken, T., Jaroszewicz, B., Kopecký, M., Máliš, F., Macek, M., Malicki, M., Naaf, T., Nagel, T.A., Ortmann-Ajkai, A., Petř́́k, P., Pielech, R., Reczynska, K., Schmidt, W., Standovár, T., Swierkosz, K., Teleki, B., Vild, O., Wulf, M., Coomes, D., 2020. Forest microclimate dynamics drive plant responses to warming. Science 80. 368. 10.1126/science.aba6880.

Zuur, A., Ieno, E., Walker, N., Saveliev, A., Smith, G., 2009. Mixed effects modelling for nested data, in: Zuur, A.F., Ieno, E.N., Walker, N.J., Saveliev, A.A., Smith, G.M. (Eds.), Mixed Effects Models and Extensions in Ecology with R. Springer, New York, NY, USA, pp. 101-142. 